Article

\title{
Biofabricated Fatty Acids-Capped Silver Nanoparticles as Potential Antibacterial, Antifungal, Antibiofilm and Anticancer Agents
}

\author{
Mohammad Azam Ansari 1,*(D), Sarah Mousa Maadi Asiri ${ }^{2}$, Mohammad A. Alzohairy ${ }^{3}$, \\ Mohammad N. Alomary ${ }^{4}$, Ahmad Almatroudi ${ }^{3, *(D)}$ and Firdos Alam Khan ${ }^{5}$ (D) \\ 1 Department of Epidemic Disease Research, Institute for Research and Medical Consultations (IRMC), \\ Imam Abdulrahman Bin Faisal University, P.O. Box 1982, Dammam 31441, Saudi Arabia \\ 2 Department of Biophysics, Institute for Research and Medical Consultations (IRMC), Imam Abdulrahman Bin \\ Faisal University, Dammam 31441, Saudi Arabia; smasiri@iau.edu.sa \\ 3 Department of Clinical Laboratory Sciences, College of Applied Medical Sciences, Qassim University, \\ Qassim 51431, Saudi Arabia; dr.alzohairy@gmail.com \\ 4 National Center for Biotechnology, Life Science and Environmental Research Institute, King Abdulaziz City \\ for Science and Technology, P.O. Box 6086, Riyadh 11451, Saudi Arabia; malomary@kacst.edu.sa \\ 5 Department of Stem Cell Biology, Institute for Research and Medical Consultations (IRMC), \\ Imam Abdulrahman Bin Faisal University, P.O. Box 1982, Dammam 31441, Saudi Arabia; fakhan@iau.edu.sa \\ * Correspondence: maansari@iau.edu.sa (M.A.A.); aamtrody@qu.edu.sa (A.A.)
}

check for

updates

Citation: Ansari, M.A.; Asiri, S.M.M.; Alzohairy, M.A.; Alomary, M.N.;

Almatroudi, A.; Khan, F.A.

Biofabricated Fatty Acids-Capped

Silver Nanoparticles as Potential

Antibacterial, Antifungal, Antibiofilm

and Anticancer Agents.

Pharmaceuticals 2021, 14, 139.

https://doi.org/10.3390/ph14020139

Academic Editor:

Daniela Montesarchio

Received: 31 December 2020

Accepted: 3 February 2021

Published: 9 February 2021

Publisher's Note: MDPI stays neutral with regard to jurisdictional claims in published maps and institutional affiliations.

Copyright: (c) 2021 by the authors. Licensee MDPI, Basel, Switzerland. This article is an open access article distributed under the terms and conditions of the Creative Commons Attribution (CC BY) license (https:// creativecommons.org/licenses/by/ $4.0 /)$.
Abstract: The current study demonstrates the synthesis of fatty acids (FAs) capped silver nanoparticles (AgNPs) using aqueous poly-herbal drug Liv52 extract (PLE) as a reducing, dispersing and stabilizing agent. The NPs were characterized by various techniques and used to investigate their potent antibacterial, antibiofilm, antifungal and anticancer activities. GC-MS analysis of PLE shows a total of 37 peaks for a variety of bio-actives compounds. Amongst them, n-hexadecanoic acid (21.95\%), linoleic acid (20.45\%), oleic acid (18.01\%) and stearic acid (13.99\%) were found predominately and most likely acted as reducing, stabilizing and encapsulation FAs in LIV-AgNPs formation. FTIR analysis of LIV-AgNPs shows some other functional bio-actives like proteins, sugars and alkenes in the soft PLE corona. The zone of inhibition was $10.0 \pm 2.2-18.5 \pm 1.0 \mathrm{~mm}, 10.5 \pm 2.5-22.5 \pm 1.5 \mathrm{~mm}$ and $13.7 \pm 1.0-16.5 \pm 1.2$ against P. aeruginosa, S. aureus and C. albicans, respectively. LIV-AgNPs inhibit biofilm formation in a dose-dependent manner i.e., $54.4 \pm 3.1 \%-10.12 \pm 2.3 \%$ (S. aureus), $72.7 \pm 2.2 \%-23.3 \pm 5.2 \%$ (P. aeruginosa) and $85.4 \pm 3.3 \%-25.6 \pm 2.2 \%$ (C. albicans), and SEM analysis of treated planktonic cells and their biofilm biomass validated the fitness of LIV-AgNPs in future nanoantibiotics. In addition, as prepared FAs rich PLE capped AgNPs have also exhibited significant $\left(p<0.05^{*}\right)$ antiproliferative activity against cultured HCT-116 cells. Overall, this is a very first demonstration on employment of FAs rich PLE for the synthesis of highly dispersible, stable and uniform sized AgNPs and their antibacterial, antifungal, antibiofilm and anticancer efficacy.

Keywords: metal nanoparticles; GC-MS; FT-IR; XRD; fatty acids; drug resistant; biofilm; colon cancer; polyherbal drug

\section{Introduction}

The growing pursuits in metal-based nanomaterials synthesis are hotly debated in several fields while acknowledging their unique physico-chemical and biomedical properties with specific advocacy for fitness in clinical settings as fascinating treatment modality, worldwide [1]. Considering that there is a wide scope to achieve desired properties in synthesized nanoparticles (NPs) including shape, size and stability by manipulating reaction conditions such as $\mathrm{pH}$, temperature, concentration of metal precursors and concentration and nature of bio-reducing agents [2-8]. Besides, surface capping or encapsulation material of NPs deserves special importance due to being directly or indirectly concerned with 
limiting toxicity and cations release, affinities towards miscellaneous components of immediate environment, and cells surface, enhanced dispersity and prolonged stability and enhanced internalization propensity in several cells [5,9]. Owing to feasibility and proven antimicrobial properties, silver NPs (AgNPs) can be argued for being the most commonly synthesized and investigated nanostructure within metallic nanomaterial's landscape, however, still yet holds consistent attention of researchers. Since ancient times, the Ag based formulations (e.g., metallic silver, silver nitrate and silver sulfadiazine) mediated clinical management of infections caused by bacteria, viruses and other eukaryotic microorganisms has been on top among metallic and metal oxides [10,11]. AgNPs have also been reported disrupting respiratory chain and cell division while releasing $\mathrm{Ag}^{+}$in order to augment enhanced bacterial killing [12]. Recently, Zhao et al. [13] reported that coating of AgNPs can result in improved functionality and corrosion resistance of magnesium structures in biomedical settings. In this line, the study of Zhang et al. [14] underscored the stabilizing role of sodium alginate on calcium alginate nano-silver phosphate hybrid (CaAlg/nano$\left.\mathrm{Ag}_{3} \mathrm{PO}_{4}\right)$ by demonstrating a clear-cut uniformity in $\mathrm{Ag}_{3} \mathrm{PO}_{4}$ NPs size $(10-60 \mathrm{~nm})$ and dispersity in CaAlg phase. Similarly, Labanni et al. [15] has revealed the three alkanolamine compounds viz. diethanolamine, monoethanolamine and triethanolamine could be used as a comprehensive capping/encapsulating medium to impregnate hydroxyapatite particles on AgNPs for antibacterial bone implants.

At one end, despite substantial increase in innovative technologies to restrain the emergence of multiple drugs resistance (MDR), there is no acclaimed antimicrobial agent to warrant the control of MDR crisis effectively. This has drifted the scientific interest towards nontraditional antimicrobial formulations to limit the MDR havoc timely. For instance, the integration of "nanoantibiotics" as new paradigms of antimicrobials in clinical settings including personnel protection equipment (e.g., gloves, masks and apron) and surgical devices were observed potentially effective to circumvent the drawbacks of traditional antibiotics [16-18]. To date, a plethora of nanomaterials, specifically metallic NPs exhibited elevated functionalities and safer administration in both, in vitro and in vivo when employed as nanoantibiotics to mitigate microbial infections [19-21]. In fact, advanced nanoantibiotics formulations can also be envisioned to offer several merits: (i) functional stability against enzymatic or $\mathrm{pH}$ degradation or inactivation, (ii) enhanced solubility and (iii) favorable biocompatibility [20]. Beyond, the co-delivery of non-toxic plant bio-actives adsorbed onto surface of bio-inspired NPs eventually enhance antimicrobial potential due to: (i) prolonged stability, (ii) greater dispersity in immediate environment, (iii) slow release of cations and (iv) enhanced intracellular uptake as compared to their bare surface NPs [22]. Nevertheless, taken the antimicrobial merits of AgNPs and low toxic herbal bioactives together, a substantial interest of scientists in MDR field inclined to combine AgNPs bio-actives such as polyphenols, tannins, alkaloids, terpenoids, long and short chained hydrocarbons and proteins to ameliorate antimicrobial efficacy against Gram-positive and Gram-negative bacteria (e.g., E. coli and S. aureus) [5,22]. Hence, within the green chemistry premises, AgNPs have been fabricated with several green extracts obtained from an individual plant, animal tissue and microbial cell culture.

Precisely, Liv52 composition generally used as poly-herbal medicine (composed of Mandur basma, Tamarix gallica and herbal extracts of Capparis spinosa, Cichorium intybus, Solanum nigrum, Terminalia arjuna and Achillea millefolium) to prevent and control of cirrhosis, a chronic liver disease [23]. Thus, considering the bio-reducing ability of poly-herbal bio-actives in Liv52 extract (PLE), we have employed aqueous PLE for bio-reduction of $\mathrm{Ag}^{+}$ions to $\mathrm{Ag}^{0}$ to obtained stable and highly monodispersed PLE capped AgNPs (LIVAgNPs) in our one-pot synthetic scheme demonstrated in Figure 2. Besides, we also examined antimicrobial trends of LIV-AgNPs against MDR Pseudomonas aeruginosa (MDRPA), methicillin-resistant Staphylococcus aureus (MRSA) and Candida albicans in planktonic as well as biofilm forms. In addition, the prepared LIV-AgNPs were also examined for their toxicity trend against cultured human colorectal carcinoma cell line (HCT-116 cells). 


\section{Results and Discussion}

\subsection{Physico-Chemical Characterization of LIV-AgNPs}

\subsubsection{Synthesis and UV-Vis Analysis of LIV-AgNPs}

Briefly, an apparent color change in the reaction mixture containing the aqueous solutions of PLE and $\mathrm{AgNO}_{3}$ in 1:3 ratios $(v / v)$, from pale yellow to light brown indicated the PLE bio-actives meditated bio-reduction of $\mathrm{Ag}^{+}$to LIV-AgNPs after 20 min at $25 \pm 5{ }^{\circ} \mathrm{C}$. The color of reaction mixture tuned into intense brown after $24 \mathrm{~h}$. The appearance of a sharp UV-Vis band at $\lambda_{\max } 428 \mathrm{~nm}$ was observed which is likely due to the surface plasmon resonance (SPR) of nascent LIV-AgNPs in colloidal solution (Figure 1a). The UV-Vis absorption peak position (400-500 nm) and formation of characteristic brown color LIV-AgNPs were found concordant with the reports published on plant mediated green synthesis of AgNPs [6]. Besides, UV-Vis absorption $\left(\lambda_{\max } 428 \mathrm{~nm}\right)$ analysis of colloidal LIV-AgNPs up to six months revealed that the NPs were highly stable as the experiments showed no significant change in SPR peak (Figure 1b).
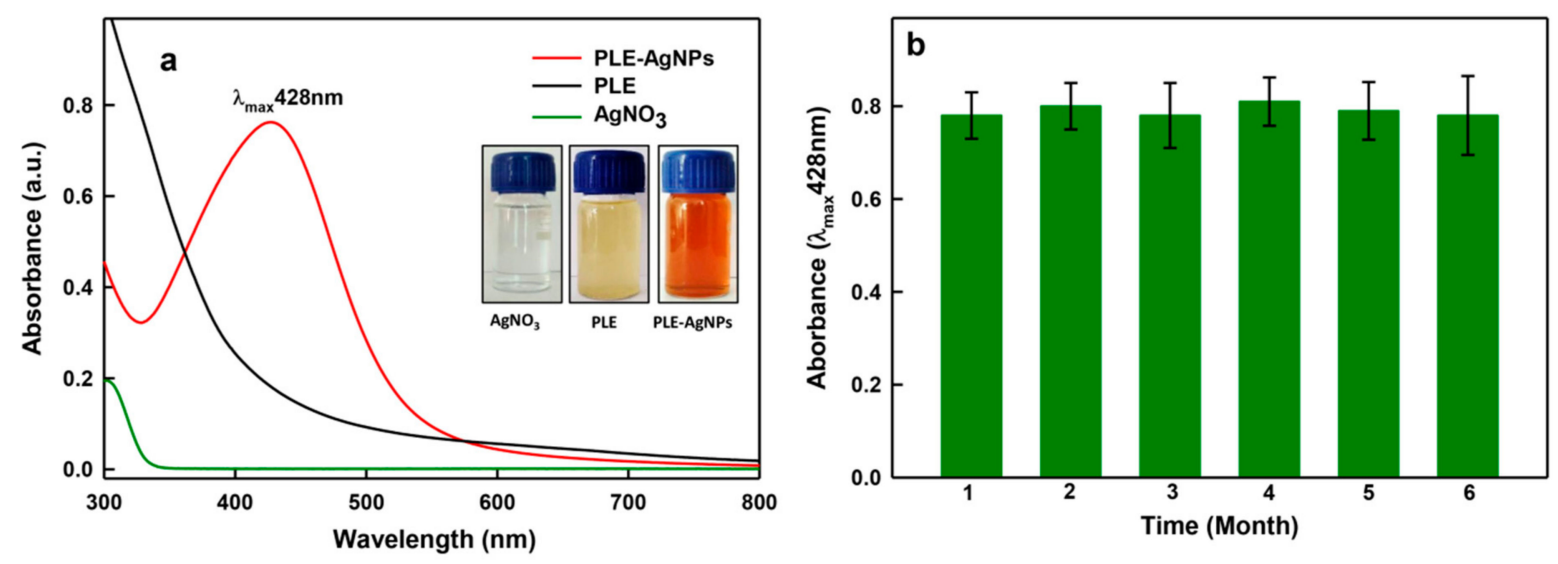

Figure 1. UV-Vis analysis of nanoparticles (NPs). Panel (a) demonstrate UV-Vis absorption peaks of pristine poly-herbal bio-actives in Liv52 extract (PLE), $\mathrm{AgNO}_{3}$ and LIV-AgNPs. Panel (b) shows stability of PLE capped silver NPs (LIVAgNPs) based on surface plasmon resonance (SPR) measurements up to six months (error bars represent the mean \pm SE of three replicates).

\subsubsection{Assessment of Bio-Actives in Pristine PLE and LIV-AgNPs by GC-MS and FTIR}

Before, synthesis of LIV-AgNPs, the pristine PLE was put through to GC-MS analysis [24] in order to presume plausible bio-active compounds that may acted as, (i) reducing agent for free metal cations $\left(\mathrm{Ag}^{+} \rightarrow \mathrm{Ag}^{0}\right)$, (ii) stabilizing agent while growth on nascent NPs in progress during nucleation phase and (iii) capping of fully grown or stabilized NPs as described in our previous study [24] was illustrated in schematic mechanism of LIV-AgNPs formation (Figure 2). The GC-MS spectrum of pristine PLE (Figure 3) reflected a total of 37 peaks $(\mathrm{P})$ for a variety of bio-actives were described in our previous study [24]. Based on their peak area, four major bio-actives in PLE were found to be long/short chained hydrocarbon fatty acids containing terminal -OH and - $\mathrm{COOH}$ groups, viz. nhexadecanoic acid (P15-21.95\%), linoleic acid (P19-20.45\%), oleic acid (P20-18.01\%) and stearic acid (P21-13.99\%) [24]. Besides, two polyphenolic bio-actives were also detected namely cardanol monoene (P27-11.92\%) and piperine (P31-1.83\%) [24] likely play axillary role in bio-reduction and capping of NPs (Table S1) [24]. Next, the FTIR-based assessment of as-prepared LIV-AgNPs also demonstrated the presence of PLE bio-actives that can be argued being responsible for bio-reduction of metal cations into nascent NPs, stabilization and capping of AgNPs. The FTIR spectrum in Figure 4a-c, demonstrates a variety of molecular signatures of PLE bio-actives adsorbed on AgNPs, which in fact appeared as sharp, broad, strong and weak signals pertaining to their band behavior such as stretching, banding and vibrations. In Figure $4 a$, a dense area of FTIR spectrum ranged 
between $3500 \mathrm{~cm}^{-1}$ and $3700 \mathrm{~cm}^{-1}$ indicated the presence a majority of PLE bio-actives associated to AgNPs surface and hence we analyzed this area at a high resolution. The observations of this section suggest the presence of medium and sharp stretching were assigned to the free -OH groups of alcohols [25]. Whereas, strong and broad stretching around $3236 \mathrm{~cm}^{-1}$ confirmed the presence of intermolecular bonded -OH and - $\mathrm{NH}$ groups of carbohydrates/lipids and primary amines, respectively, as depicted in Figure $4 \mathrm{~b}$, signify the reduction of $\mathrm{Ag}^{+}$to $\mathrm{Ag}^{0}$ and capping of AgNPs [26]. The weak vibrations between 2926 and $2850 \mathrm{~cm}^{-1}$, and $2135 \mathrm{~cm}^{-1}$ were assigned to stretching of $\mathrm{C}-\mathrm{H}$ and $\mathrm{C} \equiv \mathrm{C}$ groups of lipids and alkyne, respectively (Figure $4 \mathrm{~b}$ ). The peak at $1737 \mathrm{~cm}^{-1}$ is likely due to the presence of carbonyl (C-O) group of FAs, whereas peak at $1645 \mathrm{~cm}^{-1}$ represent carboxylic groups $(\mathrm{C}=\mathrm{O})$ of FAs and amine group $(\mathrm{N}-\mathrm{H})$ of protein (Figure $4 \mathrm{c})[24,26]$. Indeed, the appearance of $\mathrm{C}-\mathrm{O}$ and $\mathrm{C}=\mathrm{O}$ signals strongly advocate the involvement of FAs and proteins in bio-reduction and PLE bio-actives corona likely physisorbed on the surface of LIV-AgNPs. Besides, the peak at $1456 \mathrm{~cm}^{-1}$ can be ascribed to $\mathrm{CH}_{2}$ deformation or due to $\mathrm{C}-\mathrm{O}-\mathrm{H}$ bending, $1373 \mathrm{~cm}^{-1}$ represents $\mathrm{O}-\mathrm{H}$ groups of phenolic compounds, signal at $1153 \mathrm{~cm}^{-1}$ was taken as C-O-C stretching which signified the presence of carbohydrates, peak around $1026 \mathrm{~cm}^{-1}$ was assigned to O-H stretching of polyphenols (Figure 4c) [26]). Overall, our GC-MS and FTIR results strongly suggest an active role of PLE attributed FAs and polyphenolic in the synthesis of LIV-AgNPs. In same line, Rao and Trivedi [27] have also demonstrated formation of FAs encapsulated AgNPs using stearic, palmitic and lauric acids as bio-reducing and stabilizing agents. Recently, the study of Gnanakani et al. [26] exhibited the FAs namely octadecanoic, hexadecanoic and octadecanoic acids in microalgae Nannochloropsis extract as potential bio-reducing and stabilizing agents in synthesis of AgNPs. Beyond the abundance of FAs, auxiliary phenolics, proteins, carbohydrates and enzymes bio-moieties in the benign milieu of PLE can be argued to play both key roles in plant extract mediated bio-fabrication of nanomaterials [25].

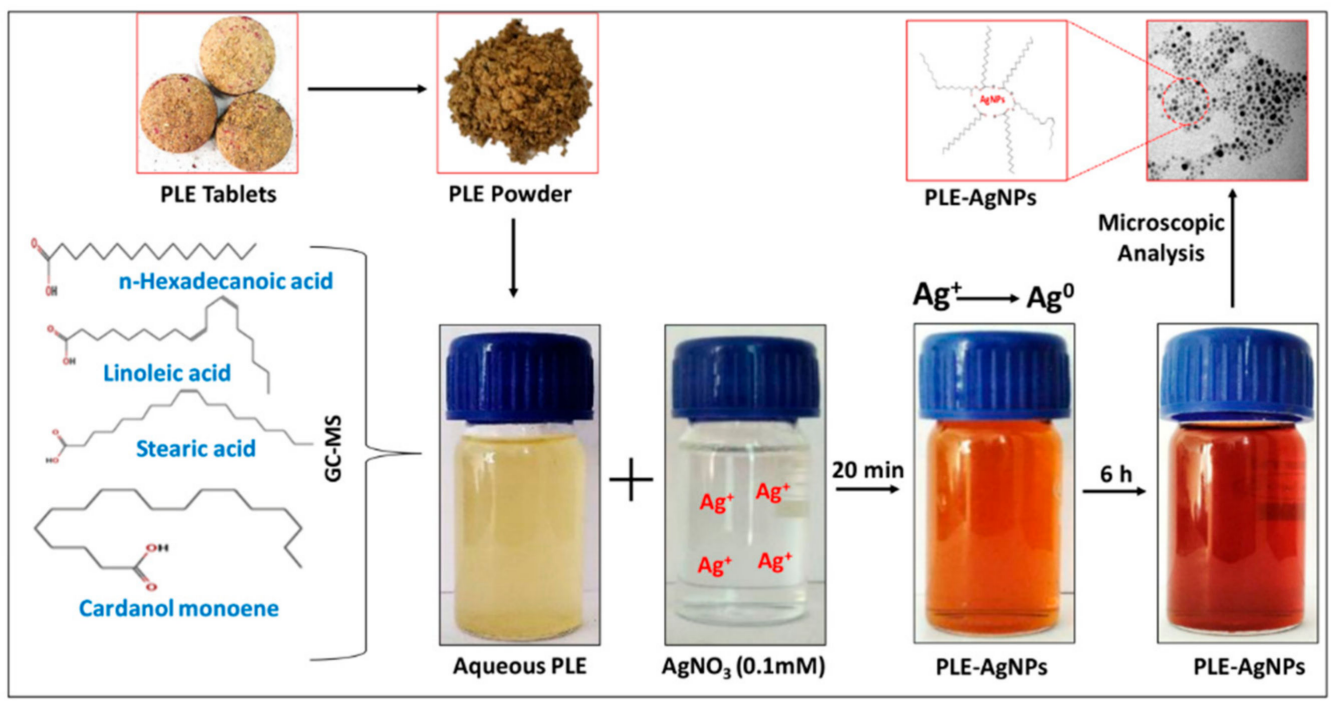

Figure 2. Schematic representation of LIV-AgNPs synthesis. 


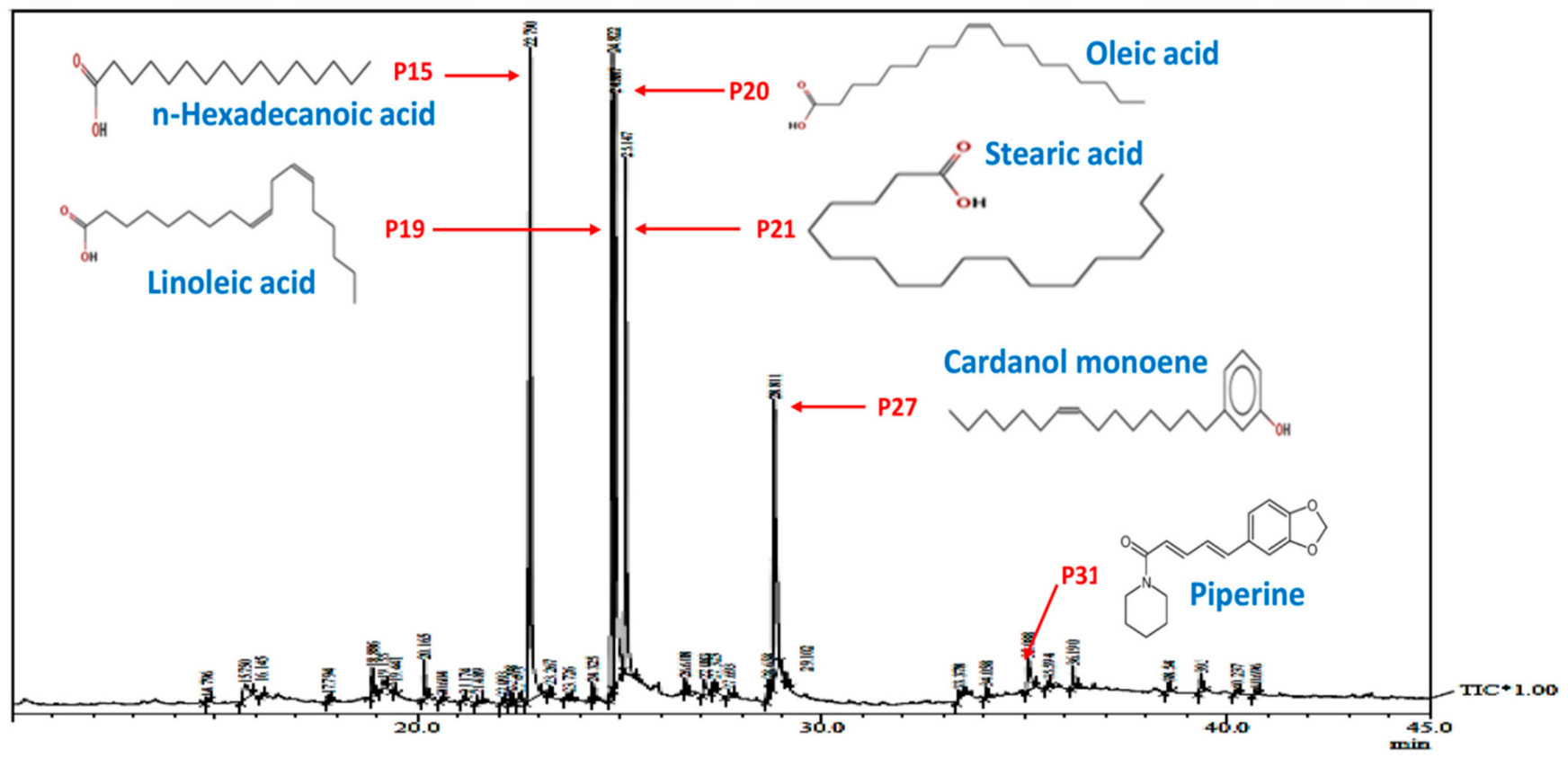

Figure 3. Gas chromatography mass-spectroscopic analysis. Typical GC-MS chromatogram of PLE showing a total 37 peaks (P) for different bio-actives compounds including six major compounds as n-hexadecanoic acid (P15-21.95\%), linoleic acid (P19-20.45\%), oleic acid (P20-18.01\%), stearic acid (P21-13.99\%), cardanol monoene (P27-11.92\%) and piperine (P31-1.83\%).
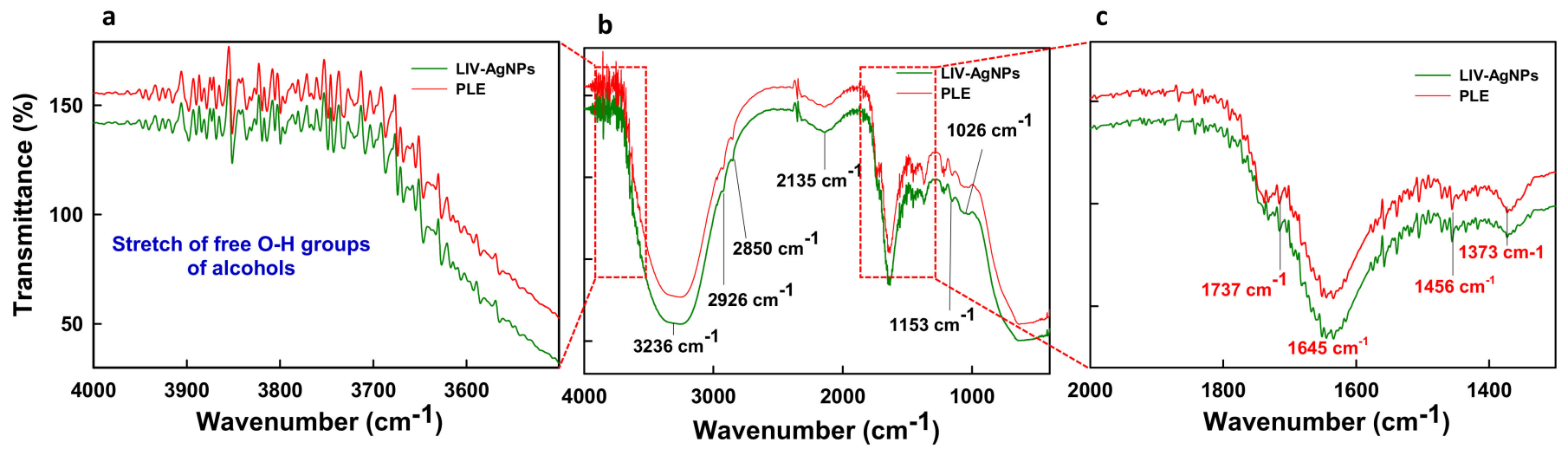

Figure 4. FTIR analysis of LIV-AgNPs. Panel $(\mathbf{a}, \mathbf{c})$ demonstrate feeble stretching signals of functional groups linked with bio-actives on PLE-alone (red) and LIV-AgNPs (green) in the range of 4000 to $3500 \mathrm{~cm}^{-1}$ and 2000 to $15,000 \mathrm{~cm}^{-1}$, at high magnification, respectively. Whereas, panel $(\mathbf{b})$ represents a comparative FTIR spectra analysis of PLE-alone and LIV-AgNPs at full scan scale at normal magnification.

\subsubsection{Electron Microscopic Properties of LIV-AgNPs}

The SEM micrographs in Figure 5a demonstrated a significant level of agglomerations in LIV-AgNPs when allowed to dry to solid powder. Besides, the elemental composition of PLE-AgNPs obtained by using EDS showed prominent peaks for carbon (30.6\%), oxygen $(44.85 \%)$ and silicon $(9.43 \%)$ along with the characteristic peak of $\mathrm{Ag}(11.39 \%)$ at approximate $3 \mathrm{keV}$ (Figure 5b). Contrarily to powdered LIV-AgNPs (Figure 5a), the TEM analysis of colloidal LIV-AgNPs solutions witnessed a great level of dispersity in aqueous environment, which was likely attributed by repulsion forces existed between two O-H groups hanging out from the soft PLE corona of AgNPs (Figure 5c). At the same time, the ImageJ software-based size determination on TEM micrographs revealed the sized of 
LIV-AgNPs was ranged between 1-10 nm with an average diameter of $5.37 \pm 1.09 \mathrm{~nm}$ (Figure 5d).

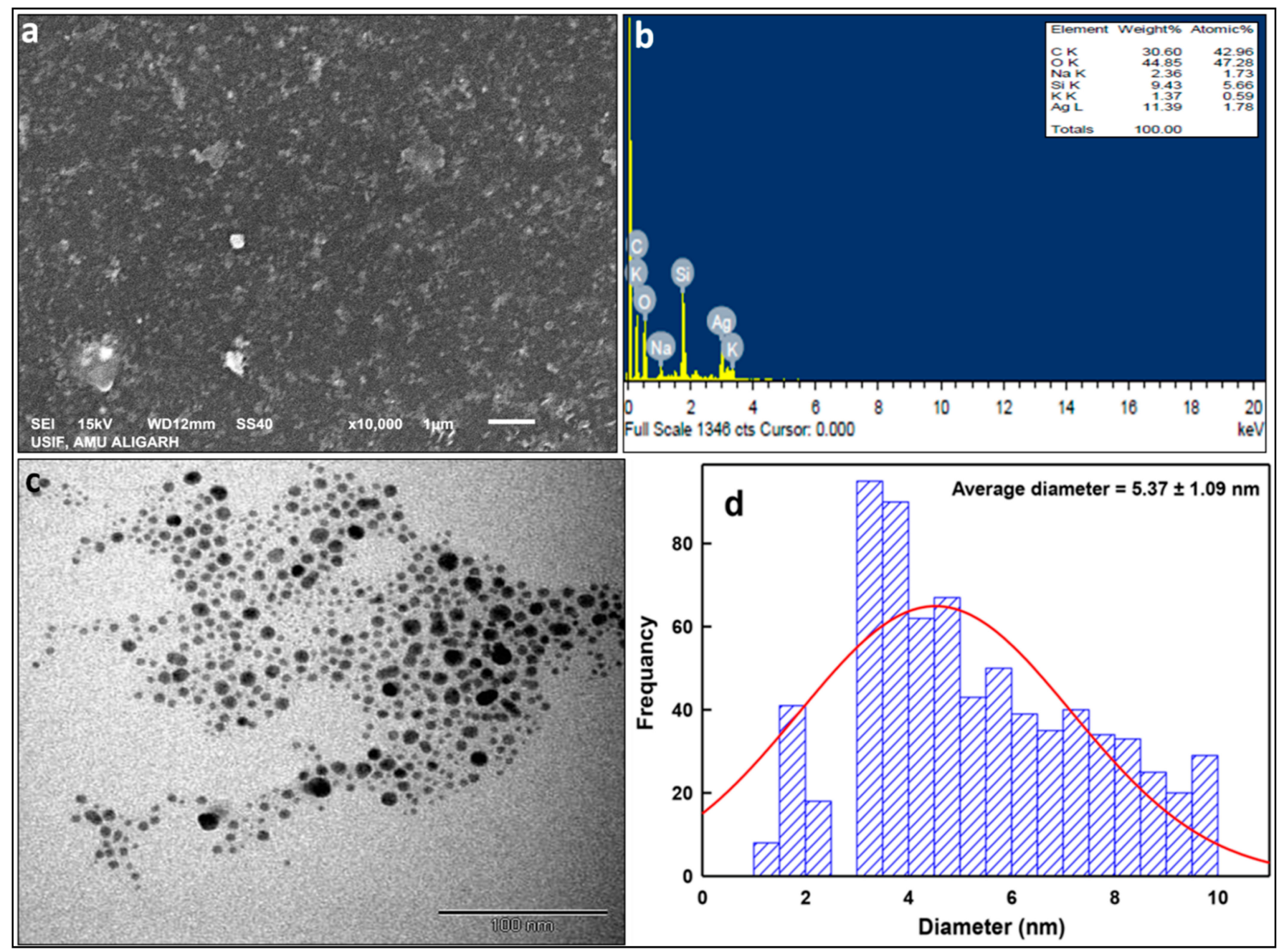

Figure 5. Electron microscopic analyses. Panel (a) shows SEM micrographs of LIV-AgNPs. Whereas, energy dispersive X-ray spectrum in panel (b) represents the percentage of Ag, C, O, NA, K and Si elements present in LIV-AgNPs. Panel (c) demonstrates TEM image of LIV-AgNPs whereas, panel (d) depicts the particle size distribution in TEM images, respectively.

\subsubsection{XRD Analysis of LIV-AgNPs}

The structure and crystallite phase of LIV-AgNPs annealed at $60{ }^{\circ} \mathrm{C}$ was obtained by $X$-ray diffraction (XRD) at $2 \theta$ degree scale in the range between 20 and $80^{\circ}$ (Figure 6). The main peaks (111), (200), (220) and (311) were observed at $38.3^{\circ}, 46.2^{\circ}, 64.5^{\circ}$ and $78.2^{\circ}$ respectively, suggest that as-prepared LIV-AgNPs are crystalline in nature $[28,29]$. In addition, the three peaks at $28^{\circ}(105)$ and $57^{\circ}(309)$, and $32.5^{\circ}$ (420) indicated some traces of hexagonal $\mathrm{Ag}_{2} \mathrm{O}$ and orthorhombic $\mathrm{Ag}_{2} \mathrm{O}_{3} \mathrm{NPs}$, respectively [30]. Besides, the XRD also demonstrated feeble and broad reflections as noise, which might be due to the presence of bioorganic compounds on the surface of AgNPs [29]. The average particle size of LIVAgNPs was estimated to be $8.53 \mathrm{~nm}$, based on full-width-at-half-maximum (FWHM) value for (111) plane of reflection. The size of the as-synthesized NPs was found in agreement to size calculated by TEM analysis $(5.37 \pm 1.09 \mathrm{~nm})$. 


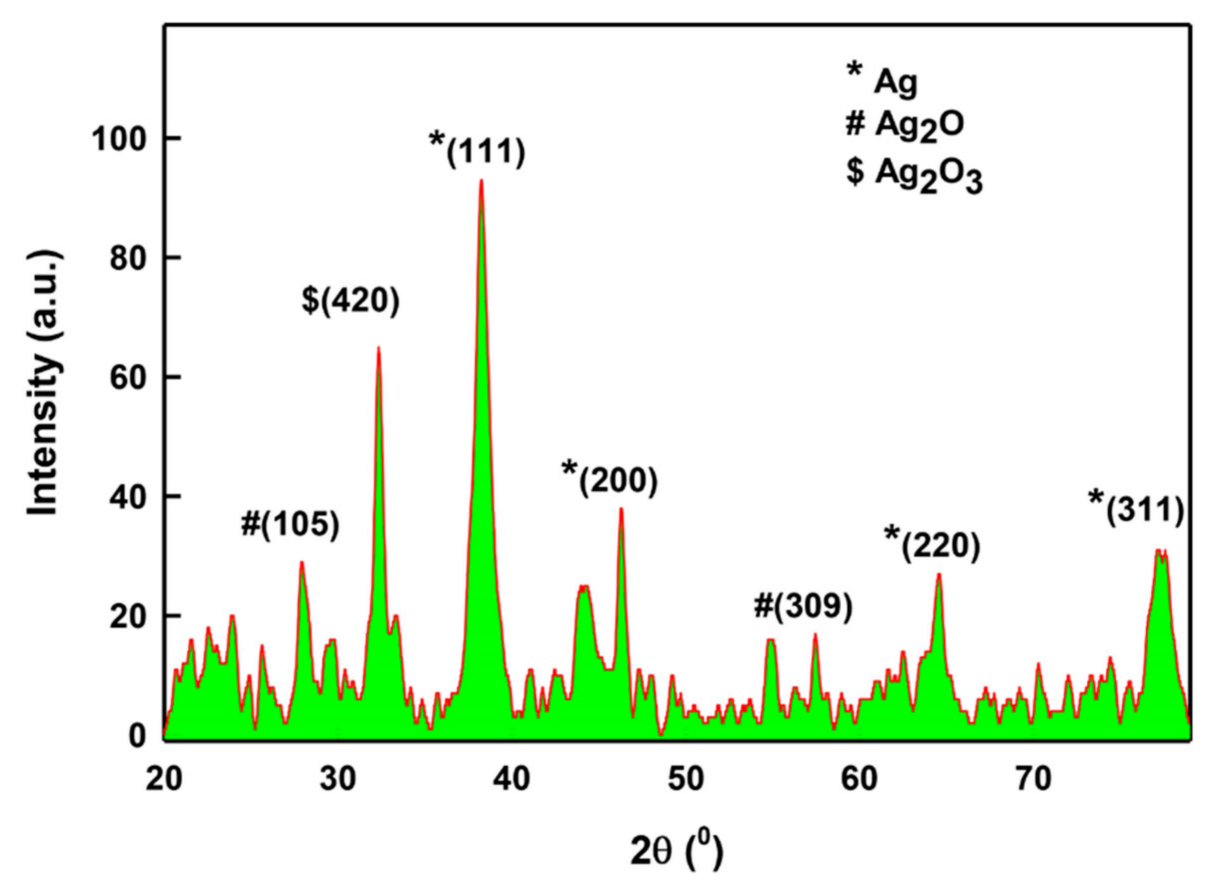

Figure 6. X-ray diffraction (XRD) pattern of LIV-AgNPs.

2.1.5. Antibacterial and Anticandidal Activity of LIV-AgNPs

Growth Inhibition Activity Assessment and Minimal Inhibitory Concentration (MIC),

Minimal Bactericidal Concentration (MBC) and Minimal Fungicidal Concentration (MFC) Values Determination

The antimicrobial activity of as prepared LIV-AgNPs $(12.5-200 \mu \mathrm{g} / \mathrm{mL})$ was assessed against the MDR Gram-negative MDR-PA and Gram-positive MRSA bacteria, and C. albicans fungal strain using well-diffusion assay. The images in Figure 7a-c demonstrate a clear-cut antibacterial and antifungal activity of LIV-AgNPs against the test strains. We have observed an apparent increase in zone of inhibition (ZOI) against MDR-PA as $10.0 \pm 2.2,13.0 \pm 2.0,13.5 \pm 1.5,16 \pm 2.0$ and $18.5 \pm 1.0 \mathrm{~mm}$ at 12.5, 25, 50, 100 and $200 \mu \mathrm{g} / \mathrm{mL}$ of LIV-AgNPs, respectively (Figure 7a, Table 1). Whereas, the increase in diameter of ZOI in Gram-positive MRSA found to be $10.5 \pm 2.5,12 \pm 0.5,16.5 \pm 1.5$, $19.5 \pm 4.5$ and $22.5 \pm 1.5 \mathrm{~mm}$, respectively, compared to control wells $(8.0 \pm 1.2)$, under the identical conditions (Figure $7 \mathrm{~b}$, Table 1 ). In the case of C. albicans fungi, higher doses of LIVAgNPs (50, 100 and $200 \mu \mathrm{g} / \mathrm{mL}$ ) could exert antifungal effects as $13.75 \pm 1.0,15 \pm 2.2$ and $16.50 \pm 1.2 \mathrm{~mm}$, respectively (Figure 7c, Table 1). Overall, these dose-dependent trends in antimicrobial activities of LIV-AgNPs were strongly supported by earlier reports on antibacterial and antifungal activities of plant bio-actives capped NPs, published elsewhere [5,31]. Besides, the MICs values of LIV-AgNPs against MDR-PA, MRSA and C. albicans were determined as $258.3 \pm 14.4,516.8 \pm 28.9$ and $758.3 \pm 38.2 \mu \mathrm{g} / \mathrm{mL}$, respectively. The MBC values for MDR-PA and MRSA were $516.7 \pm 28.9$ and $1033.3 \pm 57.7 \mu \mathrm{g} / \mathrm{mL}$, respectively, while MFC value was found as $1533.3 \pm 57.7 \mu \mathrm{g} / \mathrm{mL}$ against $C$. albicans.

\section{SEM Based Analysis of LIV-AgNPs Interaction and Cellular Damage}

To validate the antibacterial and antifungal activities of LIV-AgNPs, the treated and untreated cells of test strains were compared under SEM visualization. The results in Figure $8 \mathrm{~b}-\mathrm{c}$ exhibited significantly ruptured cell wall with deep pits and cavities formation in MDR-PA cells treated with $100 \mu \mathrm{g} / \mathrm{mL}$ of LIV-AgNPs, which were likely due to internalization and surface contact killing or on-site augmented cations mediated toxicity, as described elsewhere [25]. Under identical conditions, Gram-positive MRSA cells were observed with significant structural damage along with tremendous bulging and deep cuts in cell membrane (Figure 8e,f), which indicated increased cytoplasmic granularity likely due to prompted interaction and internalization of LIV-AgNPs as compared to 
untreated cells (Figure 8d) [5]. Similarly, in the case of fungi, the LIV-AgNPs exposed C. albicans cells showed significant changes in native morphology such as deep pits in cells compared to untreated control (Figure 8h,i) as reported elsewhere [32]. Besides, Anuj et al. [33] have demonstrated a steady release of $\mathrm{Ag}^{+}$from AgNPs and thus accumulated cations can destabilize cell membrane to combat with efflux-mediated drug resistance in Gram-negative bacteria. Recent study of Al-Kadmy [34] has also suggested that coating of AgNPs had enhanced penetrative ability through the cell wall and kills the E. coli, S. aureus and vancomycin resistant Enteroccci cells on banknote currency effectively under tentative conditions, as compared to $\mathrm{AgNO}_{3}$.
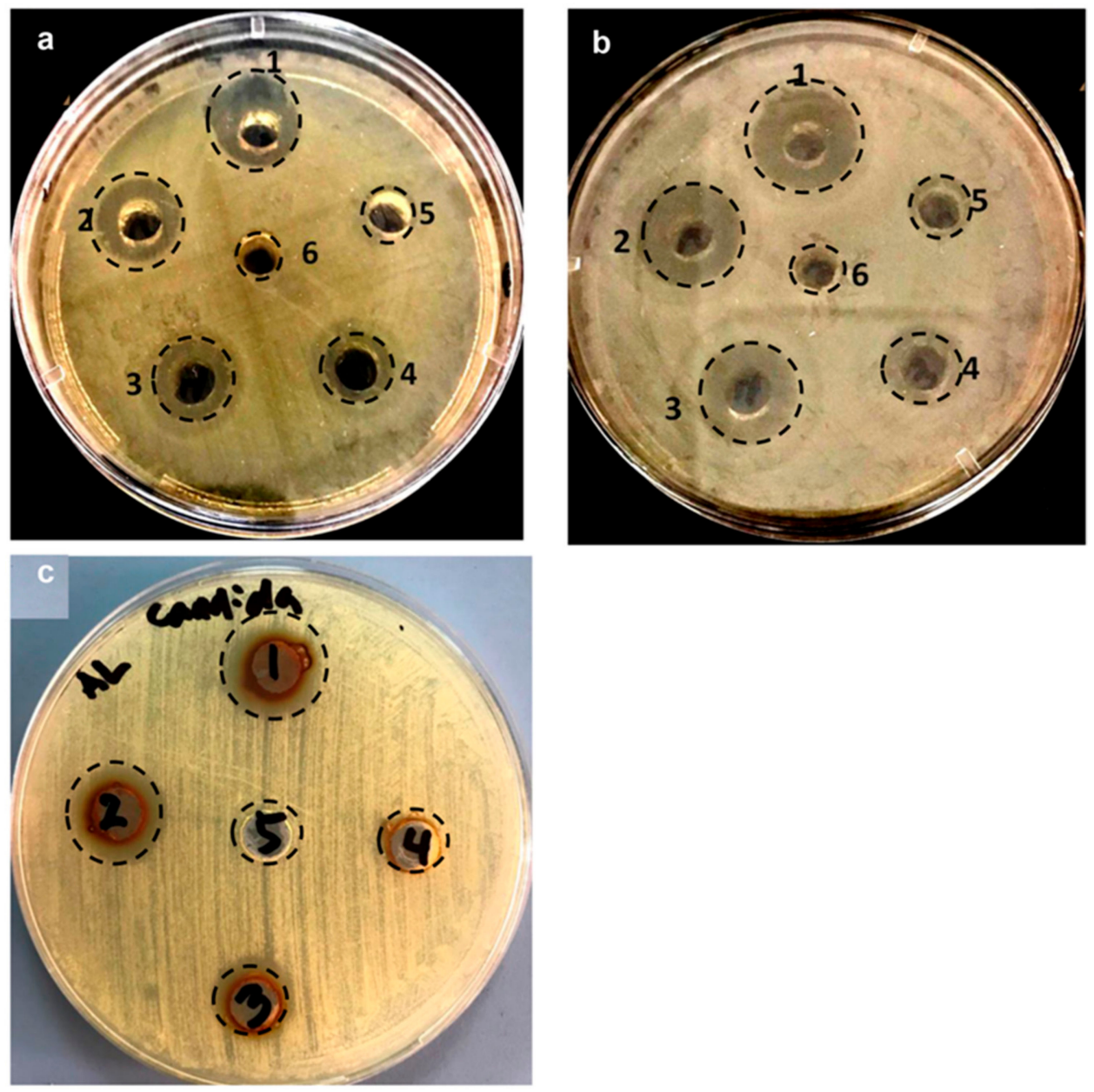

Figure 7. Assessment of antimicrobial activity of PLE alone and LIV-AgNPs by well diffusion assay. Comparative antimicrobial effects induced by, $100 \mu \mathrm{L}$ of pristine PLE (well 6) as control and increasing amounts i.e., (well 5) 12.5, (well 4) 25, (well 3) 50, (well 2) 100 and (well 1) $200 \mu \mathrm{g} / \mathrm{mL}$ of LIV-AgNPs against the Gram-negative multiple drugs resistance Pseudomonas aeruginosa (MDR-PA) (panel-(a)) and Gram-positive methicillin-resistant Staphylococcus aureus (MRSA) (panel-(b)). Panel-(c) showing zone of inhibition of C. albicans where well (5) represent control i.e., $100 \mu \mathrm{L}$ of pristine PLE, well (4) filled with 25, well (3) 50, (well 2) 100 and (well 1) $200 \mu \mathrm{g} / \mathrm{mL}$ of LIV-AgNPs, respectively. 
Table 1. Determination of zone of inhibition (in $\mathrm{mm}$ ) values of LIV-AgNPs.

\begin{tabular}{ccccc}
\hline \multirow{2}{*}{ Well No. } & \multirow{2}{*}{$\begin{array}{c}\text { LIV-AgNPs } \\
(\boldsymbol{\mu g} / \mathbf{m L})\end{array}$} & \multicolumn{2}{c}{ Diameter of Growth Inhibition Zone (mm) } \\
\cline { 3 - 5 } & 200 & MDR-PA & MRSA & C. albicans \\
\hline 1 & 100 & $18.5 \pm 1.0$ & $22.5 \pm 1.5$ & $16.5 \pm 1.2$ \\
2 & 50 & $13.5 \pm 2.0$ & $19.5 \pm 4.5$ & $15.0 \pm 2.2$ \\
3 & 25 & $13.0 \pm 2.0$ & $16.5 \pm 1.5$ & $13.7 \pm 1.0$ \\
4 & 12.5 & $10.0 \pm 2.2$ & $12.0 \pm 0.5$ & ND \\
5 & Control (PLE) & ND & ND & ND \\
6 & &
\end{tabular}

ND $=$ not detected
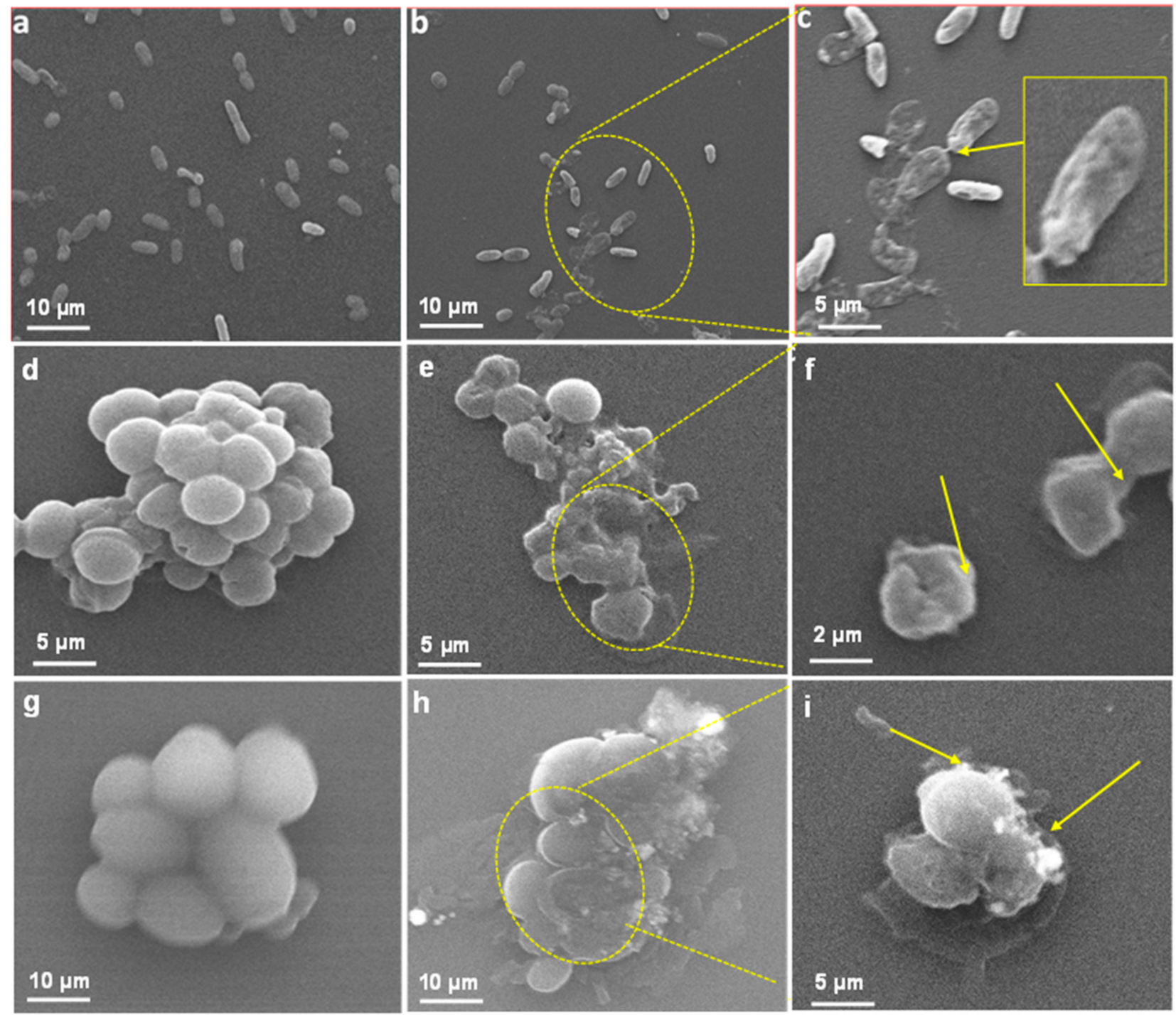

Figure 8. Interaction between LIV-AgNPs and microbial cells. Panels (a,d,g) represent SEM images of MDR-PA, MRSA and C. albicans cells in the absence of PLE-AgNPs. Whereas, panels $(\mathbf{b}, \mathbf{c}, \mathbf{e}-\mathbf{i})$, demonstrate cellular damage in MDR-PA, MRSA and C. albicans cells in presence of $100 \mu \mathrm{g} / \mathrm{mL}$ of LIV-AgNPs at low $(10-5 \mu \mathrm{m})$ and high $(5-2 \mu \mathrm{m})$ scales, respectively.

\section{Antibiofilm Studies of LIV-AgNPs}

Both, bacterial cells; Gram-negative MDR-PA and Gram-positive MRSA, and C. albicans fungi are well known for their biofilm producing ability and chronic nosocomial infections spread in hospital and associated settings $[35,36]$. Although, several metallic nanoantibi- 
otics were found having great potential either to cease or eradicate biofilm adherence [37]. Whereas, the propensity of nanoantibiotics to readily diffuse through the biofilm biomass in order to reach microbial cells seemed to be compromised due to enzymatic, non-enzymatic and $\mathrm{pH}$ mediated degradations [38]. Interestingly, the evidence suggests that FAs, either free or physisorbed on to surface of NPs can (i) suppress the regulation of quorum-sensing (QS) genes, (ii) quenched the diffusible QS signal factors such as acyl-homoserine lactones and autoinducer-2 (AI-2) and (iii) dysregulate the associated non-QS targets like efflux pumps, oxidative stress and ergosterol synthesis [39-41]. Taken together the antimicrobial potential of FAs and AgNPs, we tested LIV-AgNPs for their antibiofilm activities. In, fact, our GC-MS results prompted us to consider the LIV-AgNPs as encapsulated by PLE bio-active FAs viz. n-hexadecanoic acid (P15-21.95\%), linoleic acid (P19-20.45\%), oleic acid (P20-18.01\%) and stearic acid (P21-13.99\%) (Figure 3, Table S1) [24] and hence responsible for significant anti-biofilm activities against MDR-PA, MRSA and C. albicans. The data in Figure 9 revealed the inhibition of biofilm formation by MDR-PA cells as $23.31 \pm 5.2 \%, 31.17 \pm 3.2 \%, 40.16 \pm 5.5 \%, 53.37 \pm 4.2 \%$ and $72.75 \pm 2.2 \%$, at $31.25,62.50$, 125,250 and $500 \mu \mathrm{g} / \mathrm{mL}$ of LIV-AgNPs, respectively, versus untreated control (100\%). Under identical conditions, MRSA cells could limit the accumulate biofilm mass as $10.17 \pm$ $2.3 \%, 15.06 \pm 2.5 \%, 27.00 \pm 2.9 \%, 49.70 \pm 3.9 \%$ and $54.40 \pm 3.1 \%$, respectively. Besides bacterial cells, the biofilm formed by C. albicans was also found declined significantly $\left(p<0.05^{*}\right)$ as $25.60 \pm 2.2 \%, 35.60 \pm 1.3 \%, 41.65 \pm 1.7 \%, 59.9 \pm 3.2 \%$ and $85.44 \pm 3.3 \%$, respectively. In parallel, the SEM based comparative analyses of untreated controls (Figure 10a,c,e) and LIV-AgNPs (100 $\mu \mathrm{g} / \mathrm{mL})$ treated MDR-PA (Figure 10b), MRSA (Figure 10d) and C. albicans (Figure 10f) cells were resulted in significant disruption in their biofilm architectures. Overall, the obtained trends in biofilm formation suggest that FAs hold a great potential to inhibit or disrupt biofilm formation against several microbial pathogens, including S. aureus [42], P. aeruginosa [43] and C. albicans [39,44]. Beyond the proven antibacterial and antibiofilm track record of AgNPs [45-47], a variety of FAs have earlier been warranted as potential antimicrobial agent. For instance, study of Santhakumari et al. [48] demonstrated hexadecanoic acid $(100 \mu \mathrm{g} / \mathrm{mL})$ could interrupted the QS by loosening of biofilm architecture ( $>60 \%$ ) of vibrios spp. like Vibrio harveyi, V. parahaemolyticus, V. vulnificus and V. alginolyticus without affecting their planktonic growth. Besides, $12.8 \mu \mathrm{g} / \mathrm{mL}$ of hexadecanoic acid alone could inhibit the biofilm formation in P. aeruginosa and E.coli as $64 \%$ and $81 \%$, respectively [43]. In the same context, Soni et al. [49] also demonstrated that palmitic acid (hexadecanoic acid), stearic acid, oleic acid and linoleic acid present in extract of ground beef inhibit the auto-inducer signals activity of the reporter strain (Vibrio harveyi) and reduced E. coli biofilm formation.

\subsection{Antiproliferative Properties of LIV-AgNPs on Human Colon Cancer Cells (HCT-116) \\ Cell Viability Assay by MTT and Microscopic Analysis of HCT-116 Cells}

In addition to antimicrobial activities, PLE-capped AgNPs were also assessed for their anticancer potential. For this, human colon cancer cells were-cultured with colloidal LIV-AgNPs (10-100 $\mu \mathrm{g} / \mathrm{mL})$ for 24 and the nano-toxicity of LIV-AgNPs against HCT-116 cells was measured by employing colorimetric MTT assay. Precisely, compared untreated control cells (100 $\pm 2.5 \%)$, there is an apparent decline trend in cell viability as $86.10 \pm 5.9 \%$, $81.5 \pm 8.2 \%$ and $46.75 \pm 7.9 \%$ at 10,50 and $100 \mu \mathrm{g} / \mathrm{mL}$ of LIV-AgNPs, respectively (Figure 11). At about $100 \mu \mathrm{g} / \mathrm{mL}$, we observed a ca. $50 \%$ inhibition of the cell proliferation after $24 \mathrm{~h}$. In parallel, HCT-116 cells exposed to LIV-AgNPs (10,50 and $100 \mu \mathrm{g} / \mathrm{mL})$ were also investigated for NPs induced morphological changes. The representative micrographs of HCT-116 cells clearly demonstrate that treatment of LIV-AgNPs caused significant morphological changes (Figure $12 \mathrm{~b}-\mathrm{d}$ ) as compared to untreated cells (Figure 12a). Our results were strongly supported by the findings of Kuppusamy et al. [50] who determined the $\mathrm{IC}_{50}$ value of their Commelina nudiflora capped-AgNPs as $100 \mu \mathrm{g} / \mathrm{mL}$ against cultured HCT-116 after $24 \mathrm{~h}$. Besides, as compared to a single extract like Chlorophytum borivilianum extract functionalized AgNPs, which showed $\mathrm{IC}_{50}$ value of $254 \mu \mathrm{g} / \mathrm{mL}$ [51], the as prepared poly- 
herbal encapsulated LIV-AgNPs can act as much effective anticancer nanomedicine against human colon cancer cells. In this context, linolenic acid polymers impregnated to AgNPs have also been reported to show $82.3 \%$ inhibition rate against the rat pheochromocytoma PC 12 tumor cell line [52]. Similarly, fatty acids rich Argemone mexicana extract encapsulated AgNPs $(100 \mu \mathrm{g} / \mathrm{mL})$ were found to inhibit $80 \%$ human cervical cancer cell line (SiHa) proliferation [53]. The AgNPs have also been reported disrupting respiratory chain and cell division while releasing $\mathrm{Ag}+$ in order to augment enhanced bacterial killing. It has reported that coating of AgNPs can result in improved functionality and corrosion resistance of magnesium structures in biomedical settings [54]. With the widespread application and inevitable environmental exposure, AgNPs can be accumulated in various organs. More serious concerns are raised on the biological safety and potential toxicity of AgNPs in the central nervous system (CNS), especially in the hippocampus. Further, Chang et al. [54] investigated the biological effects and the role of PI3K/AKT/mTOR signaling pathway in AgNPs mediated cytotoxicity using the mouse hippocampal neuronal cell line (HT22 cells). They found that AgNPs reduced cell viability and induced membrane leakage in a dose-dependent manner and AgNPs also promoted the excessive production of reactive oxygen species (ROS) and caused the oxidative stress in HT22 cells [54].

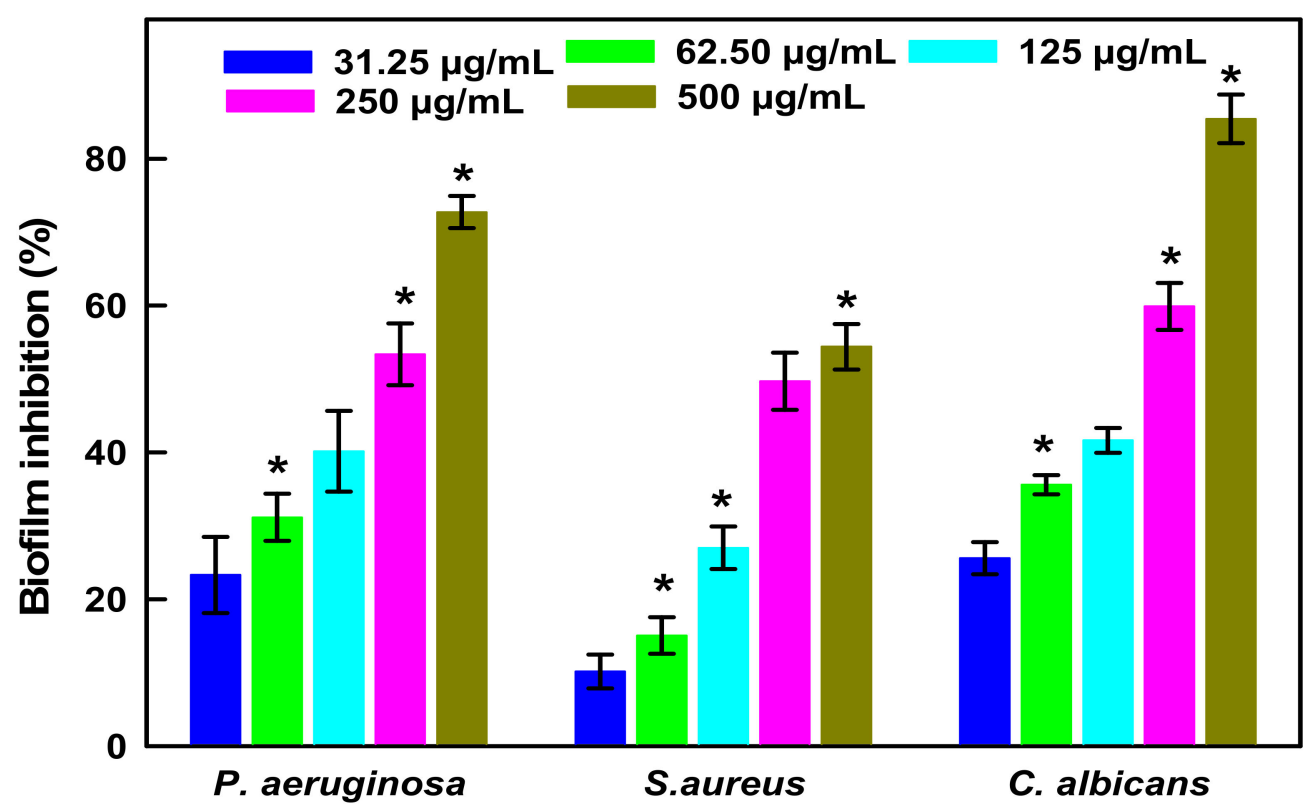

Figure 9. Antibiofilm activities. LIV-AgNPs concentration dependent inhibition in biofilm formation of MDR-PA, MRSA and C. albicans strains. The error bars represent mean \pm S.D. of two independent experiments done in triplicates. ${ }^{*} p<0.05$ versus control. 

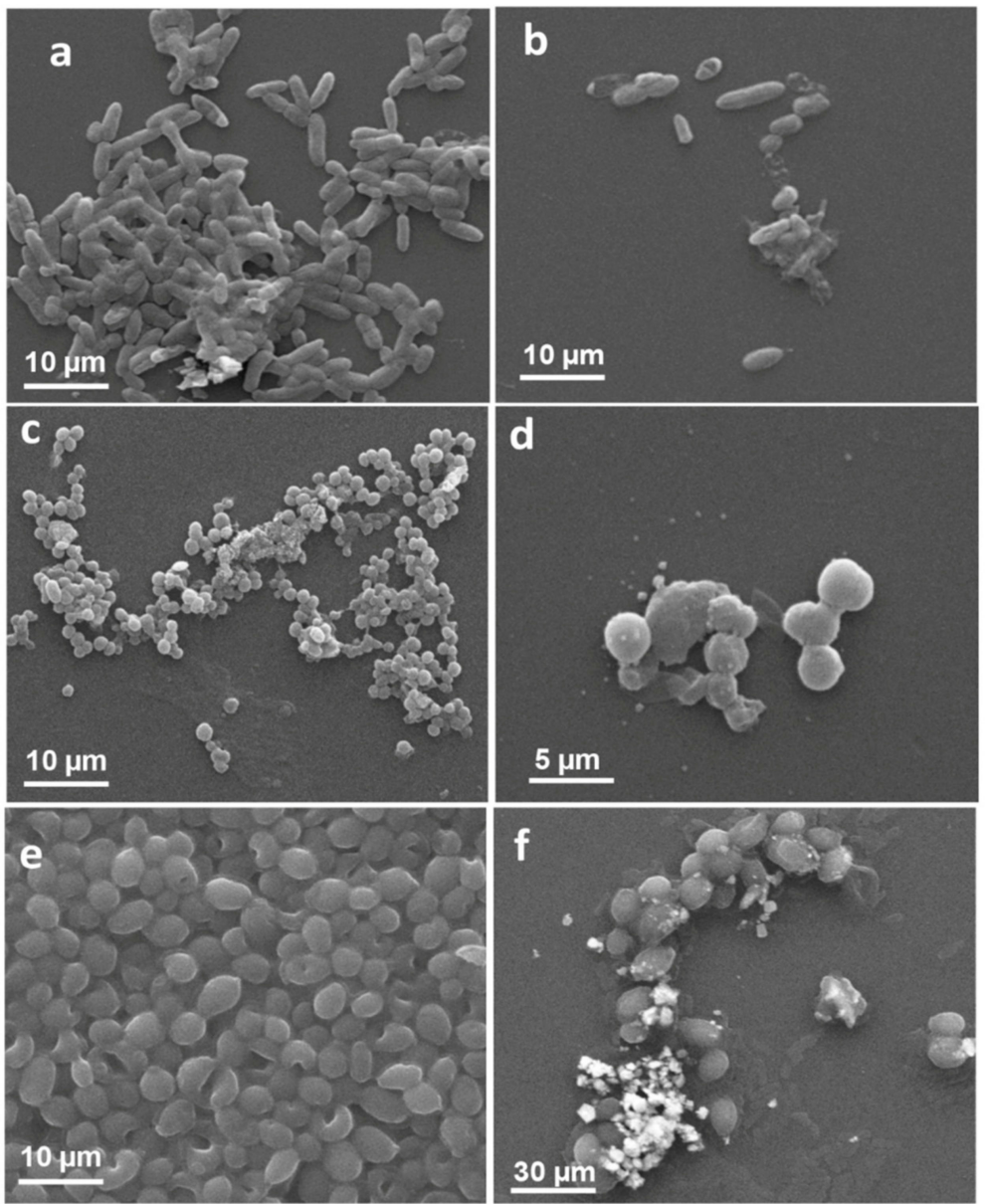

Figure 10. Microscopic analysis of biofilm inhibition. SEM micrographs of biofilm formed by MDRPA, MRSA and C. albicans strains grown in absence $(\mathbf{a}, \mathbf{c}, \mathbf{e})$ and presence $(\mathbf{b}, \mathbf{d}, \mathbf{f})$ of $100 \mu \mathrm{g} / \mathrm{mL}$ of LIV-AgNPs.

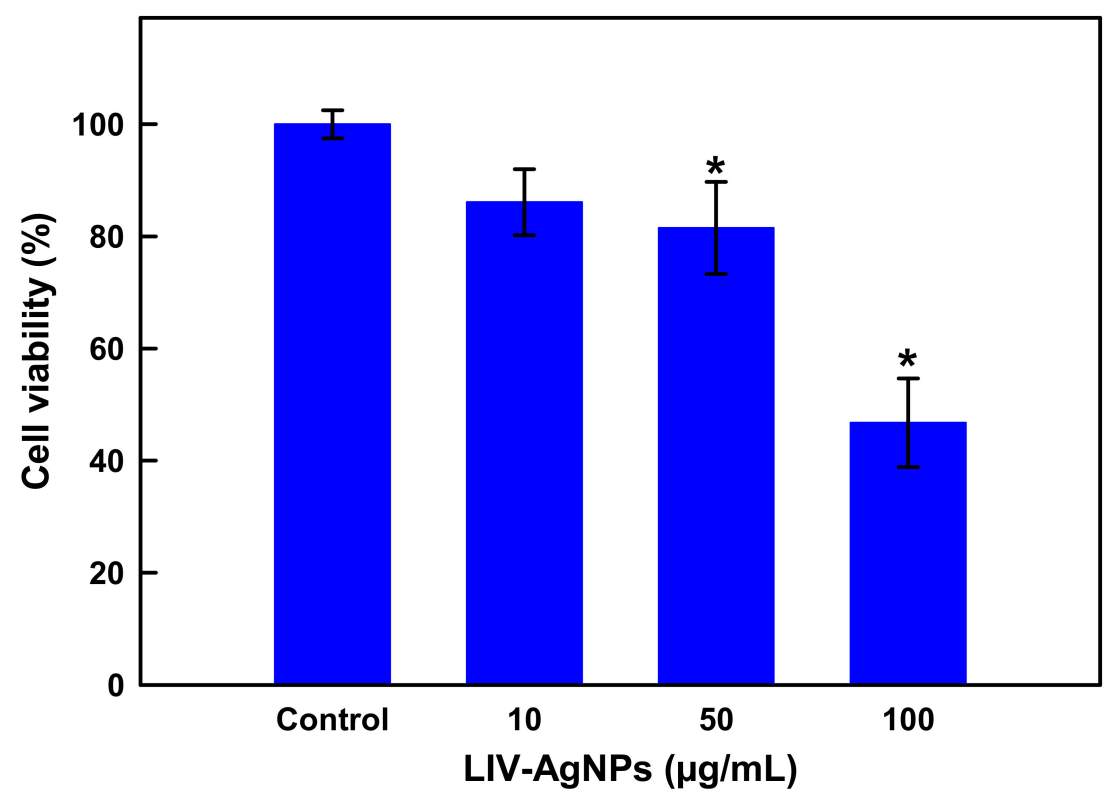

Figure 11. Dose-dependent cytotoxic effects of LIV-AgNPs against human colon cancer (HCT-116) cells quantitated by MTT assay after $24 \mathrm{~h}$ of incubation. Histograms are the mean \pm S.D. of three independent experiments done in triplicate. ${ }^{*} p<0.05$ verses untreated control. 


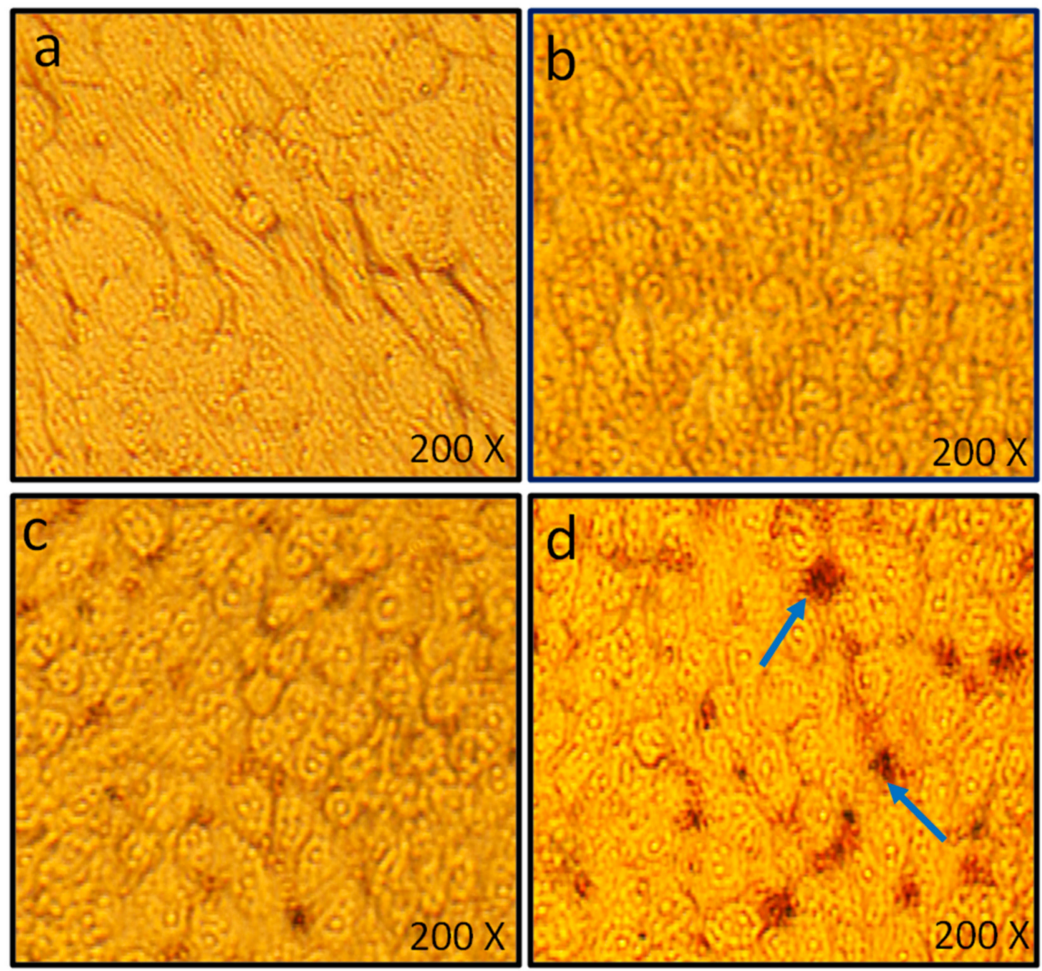

Figure 12. Microscopic analysis of HCT-116 cells exposed to varying concentrations of LIV-AgNPs for $24 \mathrm{~h}$. Cytotoxic effects were manifested as shrunken morphology, gaps between the neighboring cells and cellular detachments, which appeared as round bodies in the culture medium. Images were captured at the magnification of 200X using a bright field inverted microscope (Olympus, CKX41, Tokyo, Japan). (a) HCT-116 untreated cells, (b-d) HCT-116 cells treated with-10, 50 and $100 \mu \mathrm{g} / \mathrm{mL}$ of LIV-AgNPs, respectively.

\section{Materials and Methods}

\subsection{Preparations of Aqueous Extract of Liv52 Drug}

To prepare the fatty acids rich poly-herbal Liv52 drug extract, Liv52 tablets (Himalaya Global Holdings Ltd., Bangalore, India), were crushed to fine powder and $5 \mathrm{~g}$ was then dissolved in $100 \mathrm{~mL}$ of ultra-pure water. After $1 \mathrm{~h}$, the PLE solution was centrifuged at $12,000 \mathrm{rpm}$ for $10 \mathrm{~min}$ and so collected supernatant was additionally filtered through the Wattman paper No. 1 [24]. Thus, obtained aqueous PLE was stored at $4{ }^{\circ} \mathrm{C}$ for the green synthesis of LIV-AgNPs.

\subsection{GC-MS Based Assessment of Bio-Actives in Poly-Herbal Liv52 Drug Extract (PLE)}

Considering the fact that Liv52 is a poly-herbal composition of C. spinosa, C. intybus, S. nigrum, T. arjuna and A. millefolium extracts [23], the gas chromatography massspectroscopy (GC-MS) based analysis on methanolic extract of PLE was performed to ascertain the bio-actives compounds that plausible involved in reduction, capping and stabilization of LIV-AgNPs, following the method described elsewhere [24,31].

\subsection{Nanofabrication of Poly-Herbal liv52 Drug Extract Capped AgNPs (LIV-AgNPs)}

For the synthesis of LIV-AgNPs, PLE $(25 \mathrm{~mL})$ was mixed into $75 \mathrm{~mL}$ of $0.1 \mathrm{mM} \mathrm{AgNO}_{3}$ solution. The reaction mixture was then kept in dark at room temperature $\left(30 \pm 5^{\circ} \mathrm{C}\right)$. The color of reaction mixture was changed from pale yellow to brown after $20 \mathrm{~min}$ and became even dark brown within $24 \mathrm{~h}$, which indeed indicated the reduction of $\mathrm{Ag}^{+}$to $\mathrm{Ag}^{0} \mathrm{NPs}$ [8]. 


\subsection{Characterization of Synthesized LIV-AgNPs}

3.4.1. UV-Vis Spectroscopy and FTIR Analysis

Formation of LIV-AgNPs was monitored by using UV-Vis spectroscopy in range of $300-800 \mathrm{~nm}$ as described recently elsewhere [55]. The Fourier-transform infrared spectroscopy (FTIR) was performed to ascertain the presence of PLE bio-actives that have likely played either key or auxiliary role in the reduction $\mathrm{Ag}^{+}$to $\mathrm{Ag}^{0}$, stabilization of nano silver and capping of nascent LIV-AgNPs during synthesis [8].

\subsubsection{Electron Microscopic and EDS Analysis of LIV-AgNPs}

The shape, size and elemental composition of LIV-mediated synthesized AgNPs was carried out by scanning electron microscope (SEM), transmission electron microscope (TEM) and energy dispersive spectroscopy (EDS) following the methods described in our previous study [56].

\subsubsection{XRD Analysis of LIV-AgNPs}

The crystallinity and size of bio-synthesized LIV-AgNPs was analyzed by XRD machine as protocol described recently [57].

\subsection{Microbial and Human Carcinoma Cell Cultures}

In this study, multi-drug resistant Pseudomonas aeruginosa (laboratory strain), methicillinresistant Staphylococcus aureus (ATCC 33591) and Candida albicans (ATCC 14053) were used to investigate the antibacterial, anticandidal and antibiofilm activities of synthesized PLEAgNPs. For anticancer efficacy assessment, the human colon cancer (ATCC No. CCL-247) cell line was used. Both, the microbial and human carcinoma cell cultures were maintained as described in earlier studies $[9,58]$.

\subsection{Assessment of Antimicrobial Efficacy of LIV-AgNPs}

3.6.1. Minimal Inhibitory Concentration, Minimal Bactericidal Concentration, Minimal Fungicidal Concentration and Zone of Inhibition Determination

The antibacterial and antifungal activity of synthesized LIV-AgNPs was carried out using two-fold micro broth dilution method in the range of 62.5 to $2000 \mu \mathrm{g} / \mathrm{mL}$ against Gram-negative MDR-PA, Gram-positive MRSA and C. albicans fungal strains as method described by Ansari et al. [59]. The MIC value is defined as the lowest concentration of LIV-AgNPs at which no visible growth of bacteria and Candida was observed. After MIC determination of LIV-AgNPs, aliquots of $100 \mu \mathrm{l}$ from wells having no visible growth was seen were further spread on MHA and SDA plates for $24 \mathrm{~h}$ at $37^{\circ} \mathrm{C}$ and $28^{\circ} \mathrm{C}$, respectively, to calculate the MBC and MFC values. The lowest concentration of LIV-AgNPs that kills $100 \%$ population of tested bacteria and Candida, is considered as MBC/MFC values [59].

Further, agar well diffusion assay was performed to determine the zone of inhibition (in millimeter) of LIV-AgNPs against Gram-negative MDR-PA, Gram-positive MRSA and C. albicans as method described by Jalal et al. [8].

\subsubsection{Ultrastructural Alteration Caused by LIV-AgNPs in Bacterial and Candidal Cells}

The morphological changes caused by LIV-AgNPs in bacterial and yeast strains cells were examined by SEM analysis following protocol described in previous reports [60]. Briefly, $\sim 10^{6} \mathrm{CFU} / \mathrm{mL}$ of MDR-PA, MRSA, and C. albicans cells treated with $100 \mu \mathrm{g} / \mathrm{mL}$ of LIV-AgNPs were incubated at $16 \mathrm{~h}$ at a recommended temperature. Thereafter, washing of treated and untreated samples were performed using centrifugation and then the pellets was fixed with glutaraldehyde $(4 \% v / v)$ followed by osmium tetroxide ( $1 \%)$. After fixations, dehydration, drying and gold coating was performed and finally the effects of LIV-AgNPs on test strains of bacteria and Candida was seen under SEM at an accelerated voltage of $20 \mathrm{EV}[61]$. 


\subsubsection{Inhibition of Biofilm Forming Abilities of MDR-PA, MRSA and C. albicans}

The inhibition in biofilm formation after treatment with LIV-AgNPs was quantitated by employing the microtiter crystal violet assay [61]. Briefly, $20 \mu \mathrm{l}$ of freshly cultured MDR-PA, MRSA and C. albicans were admixed with $180 \mu$ of varying concentrations (31.25, $62.50,125,250$ and $500 \mu \mathrm{g} / \mathrm{mL}$ ) of as prepared LIV-AgNPs and then the plates were kept in incubator for $24 \mathrm{~h}$. The cells without LIV-AgNPs were considered as control group. After incubation, the content from the microtiter wells were decanted and gently washed with PBS and left for drying. The adhered biofilm biomass was then stained with crystal violet solution $(0.1 \% w / v)$ for $30 \mathrm{~min}$. The excess dyes were decanted and washed again with PBS and dried the wells completely. So stained biofilm was then solubilized with $95 \%$ ethyl alcohol and quantitated by optical density at $595 \mathrm{~nm}$ [62].

\subsubsection{Visualization of Biofilm Architecture by SEM}

Besides, the effect of LIV-AgNPs on MDR-PA, MRSA and C. albicans biofilm architecture was investigated by SEM [62]. In brief, $100 \mu \mathrm{l}$ fresh cultures of tested bacterial and yeast strains with and without LIV-AgNPs were inoculated on a glass coverslip in a 12-wells plate for overnight. After incubation, the glass coverslips were taken off and washed with PBS to remove the unadhered cells. After washing, the coverslips were fixed with glutaraldehyde $(2.5 \% \mathrm{v} / \mathrm{v})$ for $24 \mathrm{~h}$ at $4{ }^{\circ} \mathrm{C}$. After fixation, washed the coverslips again and then subjected it to dehydration, drying and gold coating. After that, the effects of LIV-AgNPs on biofilm of tested bacteria and yeast were observed using SEM [61].

\subsection{Evaluation of Anticancer Potential of LIV-AgNPs \\ 3.7.1. MTT Assay}

Human colorectal carcinoma cell line was used to investigate the anticancer potential of synthesized LIV-AgNPs at different concentrations $(10,50$ and $100 \mu \mathrm{g} / \mathrm{mL})$ in a $96-$ well cell culture plates by measuring optical density at $570 \mathrm{~nm}$ and the cell viability (\%) was estimated using given formula [62].

$$
\% \text { of cell viability }=\frac{\text { Optical density of NPs }- \text { treated cells }}{\text { Optical density of control cells }} \times 100
$$

\subsubsection{Effects of LIV-AgNPs on Morphology of HCT-116 Cells}

The effect of different concentrations (10,50 and $100 \mu \mathrm{g} / \mathrm{mL})$ of LIV-AgNPs was validated by subsequent SEM analysis of HCT-116 cells at the end of experiments under an inverted microscope equipped with a digital camera [62].

\subsection{Statistical Analysis}

Statistical analysis of data was done by one-way analysis of variance (ANOVA), HolmSidak method, multiple comparisons versus the control group (Sigma Plot 11.0, San Jose, CA, USA). The results indicate mean \pm S.D. values determined with three independent experiments done in triplicate. The level of statistical significance chosen was ${ }^{*} p<0.05$ unless otherwise stated.

\section{Conclusions}

This study demonstrates a simple one-pot procedure for synthesis of fatty acids rich aqueous extract of poly-herbal drug Liv52 stabilized LIV-AgNPs. GC-MS results demonstrated substantial proofs that PLE contributed terminal-OH and $-\mathrm{COOH}$ functional groups bearing FAs, namely n-hexadecanoic acid $(21.95 \%)$, linoleic acid $(20.45 \%)$, oleic acid $(18.01 \%)$ and stearic acid $(13.99 \%)$, that were speculated to reduce $\mathrm{Ag}^{+}$into $\mathrm{Ag}^{0}$ and followed by stabilization with soft corona formation around the nascent NPs surface during synthesis reaction. Besides, the LIV-AgNPs were found to be potential nano-therapeutics agents in order to control bacterial growth and biofilm formation against Gram-negative MDR-PA, Gram-positive MRSA and C. albicans strains, in vitro. Significant interaction of 
PLE-AgNPs with both, Gram-negative and Gram-positive bacterial and fungal strains was observed. The propensity of LIV-AgNPs interaction and internalization in planktonic cells as well as biofilm biomass appeared clearly in SEM analysis of treated experimental sets of MDR-PA, MRSA and C. albicans owing to the difference in their cell wall composition. However, the antibacterial and antibiofilm potential of LIV-AgNPs might be due to a swift surface contact through a stubborn biofilm matrix formed around the colonized cells requires further investigations to understand the mechanism of their action mode for nanoantibiotics development. In addition, the dose-dependent cytotoxicity trend of LIVAgNPs against cultured human colon cancer cells ensured that the FAs-rich PLE capped nanomaterials could act as potential anticancer nanodrugs. However, the anticancer data of LIV-AgNPs here reported are only preliminary and will be successively deeply investigated exploring their cytotoxicity on normal cells as well as the antiproliferative activity of LIV-52 extract alone, as control.

Supplementary Materials: The following are available online at https:/ /www.mdpi.com/1424-824 7/14/2/139/s1, Table S1: GS-MS analysis of poly-herbal drug Liv52 extract (PLE).

Author Contributions: Conceptualization, M.A.A. (Mohammad Azam Ansari); methodology, M.A.A. (Mohammad Azam Ansari), S.M.M.A. and F.A.K.; software, M.A.A. (Mohammad A. Alzohairy), M.N.A. and A.A.; validation, S.M.M.A. and F.A.K.; formal analysis, M.A.A. (Mohammad A. Alzohairy), M.N.A. and A.A.; investigation, M.A.A. (Mohammad Azam Ansari) and S.M.M.A.; resources, M.A.A. (Mohammad Azam Ansari) and F.A.K.; data curation, M.A.A. (Mohammad A. Alzohairy), M.N.A. and A.A.; writing-original draft preparation, M.A.A. (Mohammad Azam Ansari) and S.M.M.A.; writing—review and editing, M.A.A. (Mohammad Azam Ansari), S.M.M.A., A.A. and F.A.K.; All authors have read and agreed to the published version of the manuscript.

Funding: This work was funded by Deanship of Scientific Research Project number (2019-091-IRMC), Imam Abdulrahman Bin Faisal University, Dammam, Saudi Arabia.

Institutional Review Board Statement: Not applicable.

Informed Consent Statement: Not applicable.

Data Availability Statement: The data presented in this study are available in this manuscript.

Acknowledgments: Authors thankful to Institute for research and Medical Consultation (IRMC), Imam Abdulrahman Bin Faisal University, for providing the all kind of supports and facility.

Conflicts of Interest: The authors declare no conflict of interest.

\section{References}

1. Sharma, N.; Kaushik, S. Synthesis of bio nano particles with special reference to gold and silver metal. Mater. Today Proc. 2020, 29, 477-480. [CrossRef]

2. Shalaby, M.; Abdallah, H.; Chetty, R.; Kumar, M.; Shaban, A. Silver nano-rods: Simple synthesis and optimization by experimental design methodology. Nano-Struct. Nano-Objects 2019, 19, 100342. [CrossRef]

3. Jalal, M.; Ansari, M.A.; Alzohairy, M.A.; Ali, S.G.; Khan, H.M.; Almatroudi, A.; Siddiqui, M.I. Anticandidal activity of biosynthesized silver nanoparticles: Effect on growth, cell morphology, and key virulence attributes of Candida species. Int. J. Nanomed. 2019, 14, 4667-4679. [CrossRef] [PubMed]

4. Alomary, M.N.; Ansari, M.A. Proanthocyanins-capped biogenic $\mathrm{TiO}_{2}$ nanoparticles with enhanced penetration, antibacterial and ROS mediated inhibition of bacteria proliferation and biofilm formation: A comparative approach. Chem. A Eur. J. 2021. [CrossRef] [PubMed]

5. Ali, K.; Ahmad, B.; Ansari, S.M.; Saquib, Q.; Al-Khedhairy, A.A.; Dwivedi, S.; Alshaeri, M.; Khan, M.S.; Musarrat, J. Comparative in situ ROS mediated killing of bacteria with bulk analogue, Eucalyptus leaf extract (ELE)-capped and bare surface copper oxide nanoparticles. Mater. Sci. Eng. C 2019, 100, 747-758. [CrossRef]

6. Ansari, M.A.; Alzohairy, M.A. One-Pot Facile Green Synthesis of Silver Nanoparticles Using Seed Extract of Phoenix dactylifera and Their Bactericidal Potential against MRSA. Evid. Based Complement. Altern. Med. 2018, 2018, 1860280. [CrossRef]

7. Ashraf, J.M.; Ansari, M.A.; Khan, H.M.; Alzohairy, M.A.; Choi, I. Green synthesis of silver nanoparticles and characterization of their inhibitory effects on AGEs formation using biophysical techniques. Sci. Rep. 2016, 6, 20414. [CrossRef]

8. Jalal, M.; Ansari, M.A.; Ali, S.G.; Khan, H.M.; Eldaif, W.A.; Alrumman, S.A. Green synthesis of silver nanoparticles using leaf extract of Cinnamomum tamala and its antimicrobial activity against clinical isolates of bacteria and fungi. Int. J. Adv. Res. 2016, 4, 428-440. [CrossRef] 
9. Ali, K.; Saquib, Q.; Ahmed, B.; Siddiqui, M.A.; Ahmad, J.; Al-Shaeri, M.; Al-Khedhairy, A.A.; Musarrat, J. Bio-functionalized CuO nanoparticles induced apoptotic activities in human breast carcinoma cells and toxicity against Aspergillus flavus: An in vitro approach. Process. Biochem. 2020, 91, 387-397. [CrossRef]

10. Dibrov, P.; Dzioba, J.; Gosink, K.K.; Häse, C.C. Chemiosmotic Mechanism of Antimicrobial Activity of Ag+ in Vibrio cholerae. Antimicrob. Agents Chemother. 2002, 46, 2668-2670. [CrossRef]

11. Liu, Y.; He, L.; Mustapha, A.; Li, H.; Hu, Z.Q.; Lin, M. Antibacterial activities of zinc oxide nanoparticles against Escherichia coli O157:H7. J. Appl. Microbiol. 2009, 107, 1193-1201. [CrossRef] [PubMed]

12. Jiang, Q.; Lin, Z.; Gua, B.; Panga, C.; Wang, X. Green synthesis and immobilization of AgNPs by lumpy corn stalk as interlayer filling material for durable antibacterial. Ind. Crop. Prod. 2020, 158, 112987. [CrossRef]

13. Zhao, Y.; Chen, Y.; Wang, W.; Zhou, Z.; Shi, S.; Li, W.; Chen, M.; Li, Z. One-step in situ synthesis of nano silver-hydrotalcite coating for enhanced antibacterial and degradation property of magnesium alloys. Mater. Lett. 2020, 265, 127349. [CrossRef]

14. Zhang, Q.; Zhang, X.; Cheng, W.; Li, Q.; Li, Q. In situ-synthesis of calcium alginate nano-silver phosphate hybrid material with high flame retardant and antibacterial properties. Int. J. Biol. Macromol. 2020, 165, 1615-1625. [CrossRef] [PubMed]

15. Labanni, A.; Zulhadjri; Handayani, D.; Ohya, Y.; Arief, S. Size controlled synthesis of well-distributed nano-silver on hydroxyapatite using alkanolamine compounds. Ceram. Int. 2020, 46, 5850-5855. [CrossRef]

16. Ovais, M.; Zia, N.; Khalil, A.T.; Ayaz, M.; Khalil, A.; Ahmad, I. Nanoantibiotics: Recent developments and future prospects. In Frontiers in Clinical Drug Research Anti-Infectives; Bentham Science Publishers: Sharjah, United Arab Emirates, 2019; Volume 5, pp. 158-182.

17. Fernandez-Moure, J.S.; Evangelopoulos, M.; Colvill, K.; Van Eps, J.L.; Tasciotti, E. Nanoantibiotics: A new paradigm for the treatment of surgical infection. Nanomedicine 2017, 12, 1319-1334. [CrossRef] [PubMed]

18. Duan, F.; Feng, X.; Jin, Y.; Liu, D.; Yang, X.; Zhou, G.; Liu, D.; Li, Z.; Liang, X.-J.; Zhang, J. Metal-carbenicillin frameworkbased nanoantibiotics with enhanced penetration and highly efficient inhibition of MRSA. Biomaterials 2017, 144, 155-165. [CrossRef] [PubMed]

19. Talat, I.; Arshad, A.; Mansoor, Q. Graphene nanoplatelets $/ \mathrm{Cr}_{2} \mathrm{O}_{3}$ nanocomposites as novel nanoantibiotics: Towards control of multiple drug resistant bacteria. Ceram. Int. 2021, 47, 889-898. [CrossRef]

20. Yang, L.; Zhang, C.; Huang, F.; Liu, J.; Zhang, Y.; Yang, C.; Ren, C.; Chu, L.; Liu, B.; Liu, J. Triclosan-based supramolecular hydrogels as nanoantibiotics for enhanced antibacterial activity. J. Control. Release 2020, 324, 354-365. [CrossRef]

21. Siemer, S.; Westmeier, D.; Barz, M.; Eckrich, J.; Wünsch, D.; Seckert, C.; Thyssen, C.; Schilling, O.; Hasenberg, M.; Pang, C.; et al. Biomolecule-corona formation confers resistance of bacteria to nanoparticle-induced killing: Implications for the design of improved nanoantibiotics. Biomaterials 2019, 192, 551-559. [CrossRef]

22. Ali, K.; Ahmed, B.; Khan, M.S.; Musarrat, J. Differential surface contact killing of pristine and low EPS Pseudomonas aeruginosa with Aloe vera capped hematite $\left(\alpha-\mathrm{Fe}_{2} \mathrm{O}_{3}\right)$ nanoparticles. J. Photochem. Photobiol. B Biol. 2018, 188, 146-158. [CrossRef]

23. Huseini, H.F.; Alavian, S.; Heshmat, R.; Heydari, M.; Abolmaali, K. The efficacy of Liv-52 on liver cirrhotic patients: A randomized, double-blind, placebo-controlled first approach. Phytomedicine 2005, 12, 619-624. [CrossRef]

24. Ansari, M.A.; Asiri, S.M.M. Green synthesis, antimicrobial, antibiofilm and antitumor activities of superparamagnetic $\gamma-\mathrm{Fe}_{2} \mathrm{O}_{3}$ NPs and their molecular docking study with cell wall mannoproteins and peptidoglycan. Int. J. Biol. Macromol. 2021, 171, 44-58. [CrossRef] [PubMed]

25. Ali, K.; Dwivedi, S.; Azam, A.; Saquib, Q.; Al-Said, M.S.; Alkhedhairy, A.A.; Musarrat, J. Aloe vera extract functionalized zinc oxide nanoparticles as nanoantibiotics against multi-drug resistant clinical bacterial isolates. J. Colloid Interface Sci. 2016, 472, 145-156. [CrossRef] [PubMed]

26. Gnanakani, P.E.; Santhanam, P.; Premkumar, K.; Kumar, K.E.; Dhanaraju, M.D. Nannochloropsis Extract-Mediated Synthesis of Biogenic Silver Nanoparticles, Characterization and In Vitro Assessment of Antimicrobial, Antioxidant and Cytotoxic Activities. Asian Pac. J. Cancer Prev. 2019, 20, 2353-2364. [CrossRef] [PubMed]

27. Rao, C.R.; Trivedi, D. Synthesis and characterization of fatty acids passivated silver nanoparticles-Their interaction with PPy. Synth. Met. 2005, 155, 324-327. [CrossRef]

28. Ansari, M.A.; Khan, H.M.; Khan, A.A.; Cameotra, S.S.; Saquib, Q.; Musarrat, J. Gum arabic capped-silver nanoparticles inhibit biofilm formation by multi-drug resistant strains ofPseudomonas aeruginosa. J. Basic Microbiol. 2014, 54, 688-699. [CrossRef] [PubMed]

29. Zarei, Z.; Razmjoue, D.; Karimi, J. Green Synthesis of Silver Nanoparticles from Caralluma tuberculata Extract and its Antibacterial Activity. J. Inorg. Organomet. Polym. Mater. 2020, 30, 4606-4614. [CrossRef]

30. Boopathi, S.; Gopinath, S.; Boopathi, T.; Balamurugan, V.; RajeshKumar, R.; Sundararaman, M. Characterization and Antimicrobial Properties of Silver and Silver Oxide Nanoparticles Synthesized by Cell-Free Extract of a Mangrove-Associated Pseudomonas aeruginosa M6 Using Two Different Thermal Treatments. Ind. Eng. Chem. Res. 2012, 51, 5976-5985. [CrossRef]

31. Ali, S.G.; Ansari, M.A.; Khan, H.M.; Jalal, M.; Mahdi, A.A.; Cameotra, S.S. Crataeva nurvala nanoparticles inhibit virulence factors and biofilm formation in clinical isolates of Pseudomonas aeruginosa. J. Basic Microbiol. 2017, 57, 193-203. [CrossRef]

32. Ali, S.G.; Ansari, M.A.; Alzohairy, M.A.; Alomary, M.N.; Alyahya, S.; Jalal, M.; Khan, H.M.; Asiri, S.M.M.; Ahmad, W.; Mahdi, A.A.; et al. Biogenic Gold Nanoparticles as Potent Antibacterial and Antibiofilm Nano-Antibiotics against Pseudomonas aeruginosa. Antibiotics 2020, 9, 100. [CrossRef] [PubMed] 
33. Anuj, S.A.; Gajera, H.P.; Hirpara, D.G.; Golakiya, B.A. Bacterial membrane destabilization with cationic particles of nano-silver to combat efflux-mediated antibiotic resistance in Gram-negative bacteria. Life Sci. 2019, 230, 178-187. [CrossRef]

34. Al-Kadmy, I.M. Manufacturing silver nano-coating currencies to prevent the bacteria growing on the surface of currency. Gene Rep. 2020, 19, 100648. [CrossRef]

35. Lindsay, A.K.; Hogan, D.A. Candida albicans: Molecular interactions with Pseudomonas aeruginosa and Staphylococcus aureus. Fungal Biol. Rev. 2014, 28, 85-96. [CrossRef]

36. Rath, S.; Das, S.R.; Padhy, R.N. Surveillance of bacteria Pseudomonas aeruginosa and MRSA associated with chronic suppurative otitis media. Braz. J. Otorhinolaryngol. 2017, 83, 201-206. [CrossRef] [PubMed]

37. Das, P.; Karankar, V.S. New avenues of controlling microbial infections through anti-microbial and anti-biofilm potentials of green mono-and multi-metallic nanoparticles: A review. J. Microbiol. Methods 2019, 167, 105766. [CrossRef] [PubMed]

38. Chaudhary, R.G.; Bhusari, G.S.; Tiple, A.; Rai, A.R.; Somkuvar, S.R.; Potbhare, A.K.; Lambat, T.L.; Ingle, P.P.; Abdala, A.A. Metal/Metal Oxide Nanoparticles: Toxicity, Applications, and Future Prospects. Curr. Pharm. Des. 2019, 25, 4013-4029. [CrossRef]

39. Prasath, K.G.; Sethupathy, S.; Pandian, S.K. Proteomic analysis uncovers the modulation of ergosterol, sphingolipid and oxidative stress pathway by myristic acid impeding biofilm and virulence in Candida albicans. J. Proteom. 2019, 208, 103503. [CrossRef]

40. Nicol, M.; Alexandre, S.; Luizet, J.-B.; Skogman, M.; Jouenne, T.; Salcedo, S.P.; Dé, E. Unsaturated Fatty Acids Affect Quorum Sensing Communication System and Inhibit Motility and Biofilm Formation of Acinetobacter baumannii. Int. J. Mol. Sci. 2018, 19, 214. [CrossRef]

41. Murzyn, A.; Krasowska, A.; Stefanowicz, P.; Dziadkowiec, D.; Łukaszewicz, M. Capric Acid Secreted by S. boulardii Inhibits C. albicans Filamentous Growth, Adhesion and Biofilm Formation. PLoS ONE 2010, 5, e12050. [CrossRef]

42. Kim, Y.-G.; Lee, J.-H.; Raorane, C.J.; Oh, S.T.; Park, J.G.; Lee, J. Herring Oil and Omega Fatty Acids Inhibit Staphylococcus aureus Biofilm Formation and Virulence. Front. Microbiol. 2018, 9, 1241. [CrossRef] [PubMed]

43. Wenderska, I.B.; Chong, M.; McNulty, J.; Wright, G.D.; Burrows, L.L. Palmitoyl-dl-Carnitine is a Multitarget Inhibitor of Pseudomonas aeruginosa Biofilm Development. ChemBioChem 2011, 12, 2759-2766. [CrossRef] [PubMed]

44. Muthamil, S.; Balasubramaniam, B.; Balamurugan, K.; Pandian, S.K. Synergistic Effect of Quinic Acid Derived from Syzygium cumini and Undecanoic Acid Against Candida spp. Biofilm and Virulence. Front. Microbiol. 2018, 9, 2835. [CrossRef]

45. El-Batal, A.I.; Elkodous, M.A.; El-Sayyad, G.S.; Al-Hazmi, N.E.; Gobara, M.; Baraka, A. Gum Arabic polymer-stabilized and Gamma rays-assisted synthesis of bimetallic silver-gold nanoparticles: Powerful antimicrobial and antibiofilm activities against pathogenic microbes isolated from diabetic foot patients. Int. J. Biol. Macromol. 2020, 165, 169-186. [CrossRef]

46. Adebayo-Tayo, B.C.; Salaam, A.; Ajibade, A. Green synthesis of silver nanoparticle using Oscillatoria sp. extract, its antibacterial, antibiofilm potential and cytotoxicity activity. Heliyon 2019, 5, e02502. [CrossRef]

47. Korkmaz, N.; Ceylan, Y.; Hamid, A.; Karadağ, A.; Bülbül, A.S.; Aftab, M.N.; Çevik, Ö.; Şen, F. Biogenic silver nanoparticles synthesized via Mimusops elengi fruit extract, a study on antibiofilm, antibacterial, and anticancer activities. J. Drug Deliv. Sci. Technol. 2020, 59, 101864. [CrossRef]

48. Santhakumari, S.; Nilofernisha, N.M.; Ponraj, J.G.; Pandian, S.K.; Ravi, A.V. In vitro and in vivo exploration of palmitic acid from Synechococcus elongatus as an antibiofilm agent on the survival of Artemia franciscana against virulent vibrios. J. Invertebr. Pathol. 2017, 150, 21-31. [CrossRef]

49. Soni, K.A.; Jesudhasan, P.; Cepeda, M.; Widmer, K.; Jayaprakasha, G.K.; Patil, B.S.; Hume, M.E.; Pillai, S.D. Identification of Ground Beef-Derived Fatty Acid Inhibitors of Autoinducer-2-Based Cell Signaling. J. Food Prot. 2008, 71, 134-138. [CrossRef] [PubMed]

50. Kuppusamy, P.; Ichwan, S.J.A.; Al-Zikri, P.N.H.; Suriyah, W.H.; Soundharrajan, I.; Govindan, N.; Maniam, G.P.; Yusoff, M. In Vitro Anticancer Activity of Au, Ag Nanoparticles Synthesized Using Commelina nudiflora L. Aqueous Extract Against HCT-116 Colon Cancer Cells. Biol. Trace Elem. Res. 2016, 173, 297-305. [CrossRef]

51. Huang, F.; Long, Y.; Liang, Q.; Purushotham, B.; Swamy, M.K.; Duan, Y. Safed Musli (Chlorophytum borivilianum L.) CallusMediated Biosynthesis of Silver Nanoparticles and Evaluation of their Antimicrobial Activity and Cytotoxicity against Human Colon Cancer Cells. J. Nanomater. 2019, 2019, 2418785. [CrossRef]

52. Cao, Y.; Shi, L.-H.; Yu, X.-H.; Wang, C.-F.; Wang, H.-J. Conjugated linolenic acid polymer dressings impregnated with silver nano-crystals: Fabrication and dual inhibition functions assessment on tumor cells and microorganisms. Chem. Eng. J. 2014, 245, 150-157. [CrossRef]

53. Jha, A.K.; Prasad, K. Green synthesis of silver nanoparticles and its activity on SiHa cervical cancer cell line. Adv. Mater. Lett. 2014, 5, 501-505. [CrossRef]

54. Chang, X.; Wang, X.; Li, J.; Shang, M.; Niu, S.; Zhang, W.; Li, Y.; Sun, Z.; Gan, J.; Li, W.; et al. Silver nanoparticles induced cytotoxicity in HT22 cells through autophagy and apoptosis via PI3K/AKT/mTOR signaling pathway. Ecotoxicol. Environ. Saf. 2021, 208, 111696. [CrossRef] [PubMed]

55. Almatroudi, A.; Khadri, H.; Azam, M.; Rahmani, A.H.; Al Khaleefah, F.K.; Khateef, R.; Ansari, M.A.; Allemailem, K.S. Antibacterial, Antibiofilm and Anticancer Activity of Biologically Synthesized Silver Nanoparticles Using Seed Extract of Nigella sativa. Processes 2020, 8, 388. [CrossRef]

56. Farouk, F.; Abdelmageed, M.; Ansari, M.A.; Azzazy, H.M.E.-S. Synthesis of magnetic iron oxide nanoparticles using pulp and seed aqueous extract of Citrullus colocynth and evaluation of their antimicrobial activity. Biotechnol. Lett. 2020, 42, 231-240. [CrossRef] [PubMed] 
57. Kollur, S.P.; Prasad, S.K.; Ansari, M.A.; Alzohairy, M.A.; Alomary, M.N.; Alyahya, S.; Srinivasa, C.; Murali, M.; Ankegowda, V.M.; Shivamallu, C. Tumoricidal and Bactericidal Properties of ZnONPs Synthesized Using Cassia auriculata Leaf Extract. Biomolecules 2020, 10, 982. [CrossRef]

58. Rehman, S.; Jermy, B.R.; Asiri, S.M.; Shah, M.A.; Farooq, R.; Ravinayagam, V.; Ansari, M.A.; AlSalem, Z.; Al Jindan, R.; Reshi, Z.; et al. Using Fomitopsis pinicola for bioinspired synthesis of titanium dioxide and silver nanoparticles, targeting biomedical applications. RSC Adv. 2020, 10, 32137-32147. [CrossRef]

59. Ansari, M.A.; Khan, H.M.; Khan, A.A.; Pal, R.; Cameotra, S.S. Antibacterial potential of $\mathrm{Al}_{2} \mathrm{O}_{3}$ nanoparticles against multidrug resistance strains of Staphylococcusaureus isolated from skin exudates. J. Nanoparticle Res. 2013, 15, 1970. [CrossRef]

60. Shukla, A.K.; Alam, J.; Ansari, M.A.; Alhoshan, M.; Ali, F.A.A. Antimicrobial and antifouling properties of versatile PPSU/carboxylated GO nanocomposite membrane against Gram-positive and Gram-negative bacteria and protein. Environ. Sci. Pollut. Res. 2018, 25, 34103-34113. [CrossRef]

61. Ansari, M.A.; Albetran, H.M.; Alheshibri, M.H.; Timoumi, A.; Algarou, N.A.; Akhtar, S.; Slimani, Y.; Almessiere, M.; AlAhmari, F.; Baykal, A.; et al. Synthesis of Electrospun $\mathrm{TiO}_{2}$ Nanofibers and Characterization of Their Antibacterial and Antibiofilm Potential against Gram-Positive and Gram-Negative Bacteria. Antibiotics 2020, 9, 572. [CrossRef]

62. Baig, U.; Ansari, M.A.; Gondal, M.A.; Akhtar, S.; Khan, F.A.; Falath, W.S. Single step production of high-purity copper oxidetitanium dioxide nanocomposites and their effective antibacterial and anti-biofilm activity against drug-resistant bacteria. Mater. Sci. Eng. C 2020, 22, 110992. [CrossRef] [PubMed] 